\title{
Remote Sensing Data in Wind Velocity Field Modelling: a Case Study from the Sudetes (SW Poland)
}

\author{
KACPER JANCEWICZ ${ }^{1}$
}

\begin{abstract}
The phenomena of wind-field deformation above complex (mountainous) terrain is a popular subject of research related to numerical modelling using GIS techniques. This type of modelling requires, as input data, information on terrain roughness and a digital terrain/elevation model. This information may be provided by remote sensing data. Consequently, its accuracy and spatial resolution may affect the results of modelling. This paper represents an attempt to conduct wind-field modelling in the area of the Śnieżnik Massif (Eastern Sudetes). The modelling process was conducted in WindStation 2.0.10 software (using the computable fluid dynamics solver Canyon). Two different elevation models were used: the Global Land Survey Digital Elevation Model (GLS DEM) and Digital Terrain Elevation Data (DTED) Level 2. The terrain roughness raster was generated on the basis of Corine Land Cover 2006 (CLC 2006) data. The output data were post-processed in ArcInfo 9.3.1 software to achieve a high-quality cartographic presentation. Experimental modelling was conducted for situations from 26 November 2011, 25 May 2012, and 26 May 2012, based on a limited number of field measurements and using parameters of the atmosphere boundary layer derived from the aerological surveys provided by the closest meteorological stations. The model was run in a $100-\mathrm{m}$ and $250-\mathrm{m}$ spatial resolution. In order to verify the model's performance, leave-one-out cross-validation was used. The calculated indices allowed for a comparison with results of former studies pertaining to WindStation's performance. The experiment demonstrated very subtle differences between results in using DTED or GLS DEM elevation data. Additionally, CLC 2006 roughness data provided more noticeable improvements in the model's performance, but only in the resolution corresponding to the original roughness data. The best input data configuration resulted in the following mean values of error measure: root mean squared error of velocity $=1.0 \mathrm{~m} / \mathrm{s}$ and mean absolute error of direction $=30^{\circ}$. The author concludes that, within specific meteorological conditions (relatively strong and constant synoptic forcing) and using the aforementioned input data, the Canyon model provides fairly acceptable results. Similarly, the quality of the presented remote sensing data is suitable for wind velocity modelling in the proposed resolution. However, CLC 2006 land use data should be first verified with a higher-resolution satellite or aerial imagery.
\end{abstract}

1 Department of Cartography, University of Wrocław, pl. Uniwersytecki 1, 50-137 Wrocław, Poland. E-mail: kacper.jancewicz@uni.wroc.pl
Key words: Remote sensing data, CFD models, wind velocity modelling, the Sudetes, Poland.

\section{Introduction}

The issue of terrain impact on air flow in the atmospheric boundary layer is often considered in meteorological research, especially in the context of mesoscale and microscale anemological phenomena (BARRY 2008). Orographically induced air flow modifications, observed in mountainous or hilly regions of the Earth, became a subject of studies related to numerical modelling, including GIS techniques. Within this scope, two general approaches may be distinguished. The first is based on indirect evaluation of potential anemological conditions according to land surface parameters (BöHNER and Antonić 2007). The second is direct modelling, which requires considerable computational power and detailed input data.

Direct modelling of the wind field may be conducted in mesoscale and microscale, regardless of the model type. It is important to distinguish between meteorological models and computational fluid dynamics (CFD) models. Dynamic mesoscale models like HIRLAM (UNDÉN et al. 2002) and WRF (SkAmarock et al. 2005) provide a more realistic physical description of the atmosphere; they are capable of simulating synoptic processes and the interactions between the Earth's surface and atmosphere (TRuhetz 2010). On the other hand, the complexity of these models requires extensive computational resources. Thus, their spatial resolution usually does not exceed $5 \mathrm{~km}$. CFD models, often defined as diagnostic models (RAтTo et al. 1994; 
TRuhetz 2010), have been developed since the 1970s (JACKSON and HunT 1975). Models from this group are capable of simulating only steady-state flows. In consequence, they are suited to simulate orographic speed-up effects, but cannot be expected to solve any dynamic process like flow splitting, vortex shedding or thermal induced circulation (TRUHETZ 2010). The continuous growth of available computational power facilitates the development of more sophisticated CFD-models which are usually based on NavierStokes equations but differ in numerical approaches and turbulence models (direct numerical simulation, Reynolds-averaged Navier-Stokes, large eddy simulation) (UChida and Онуа 2003; Undheim 2005). Regardless of the technical details of a model, any simulation strongly depends on wind fields generated from observational data, which are used to initialize the model and thereby determine the model's performance (LoPES 2003, 2011; TRUHETZ 2010). Currently, a popular approach to achieve more detailed initial wind fields assumes the use of data from re-analysis driven dynamic mesoscale models; a good example is the application of MM5 (dynamic) and CALMET (diagnostic) models (BARNA and LAMB 2000; Chandrasekar et al. 2003; Truhetz 2010).

Diagnostic models, while relatively simplified, are rather used to acquire high-resolution phenomena simulation (UNDHEIM 2005). The studies on diagnostic modelling of wind velocity are usually executed within a resolution higher than (or equal) $1 \mathrm{~km}$. The results of the evaluation of models vary depending on resolution, terrain complexity and time span. For example, evaluation of CALMET at the test-site in Nevada (1-km grid spacing) provided a mean velocity $\mathrm{RMSE}=1.7 \mathrm{~m} / \mathrm{s}$ (Cox et al. 2005); the application of the same model (and resolution) in long-term simulations in the south-central region of Chile provided RMSE- $1.03 \mathrm{~m} / \mathrm{s}$ (Morales et al. 2012). On the other hand, short-term simulations in the Alpine region, using CONDOR and MINERVE models (500-m grid spacing) provided a mean RMSE of 0.68 and $0.65 \mathrm{~m} / \mathrm{s}$, respectively (Desiato et al. 1998). Experimental evaluation of Meteodyn WT and WindMap models, conducted on four different test sites and using relatively high spatial resolution (50$\mathrm{m}$ grid spacing) resulted in a RMSE ranging from 0.75 to $1.02 \mathrm{~m} / \mathrm{s}$ (BeAUCAGE and Brower 2012).
Modelling of wind field using the aforesaid techniques requires topographic information in addition to the necessary meteorological input data. In this case, the most relevant are digital elevation and vegetation (land use) data (EMEIS and KNOCHE 2007). Both types of data may be provided by remote sensing technology. Freely accessible elevation models developed on the basis of satellite imagery, such as Global Land Survey Digital Elevation Model (GLS DEM), Shuttle Radar Topography Mission (SRTM) or Advanced Spaceborne Thermal Emission and Reflection Radiometer Global Digital Elevation Model (ASTER GDEM), cover the majority of the Earth's surface (NELSON et al. 2007). The same situation applies to land cover information derived from satellite imagery (Landsat TM and ETM+). In consequence, the accuracy and spatial resolution of the aforementioned data may affect the results of the modelling. Accordingly, experimental studies on remote sensing data usage seem to be indispensable in order to obtain an information about the roughness patterns of the land surface; the precision of this type of input data should be appropriate to the spatial resolution of the model (WAKEs et al. 2010).

Within the scope of wind velocity modelling, the area of the Sudetes proves particularly interesting due to high intensity of orographically induced anemological phenomena. The highest wind speed values are typical for the ridges in the Karkonosze, the Śnieżnik Massif and Hruby Jesenik where, besides the impact of orography, a significant role is played by low roughness length values determined by the existing types of vegetation (SOBIK and Błaś 2010).

Based on the current state of climatologic studies in the Sudetes, it is apparent that the anemological conditions of the selected mountain range, the Śnieżnik Massif, are not as thoroughly investigated as they probably deserve (PIASECKI 1996). Within the mentioned area, any potential attempts of numerical approximation of wind field encounter an additional obstacle: lack of long-term meteorological data series. This is in part a consequence of low density and irregular distribution of working synoptic stations inside the entire area of the Sudetes. As a result, in the current conditions and within the selected area, a feasible approach of anemological studies (using GIS and remote sensing techniques) should be based on 
series of short-term field measurement. Such studies may be valuable as they contribute to extending knowledge on the local meteorological phenomena.

This study constitutes an attempt of wind-field modelling in a part of the Śnieżnik Massif. The main objectives of the study involved:

1. Validation of the chosen CFD solver's performance in terms of limited input data based on wind velocity field measurements taken at height of $2 \mathrm{~m}$ above ground.

2. Validation of usefulness of GLSDEM and Corine Land Cover 2006 data in the process of modelling based on input data referred to in item 1 .

\section{Study Area}

The Śnieżnik Massif is the second-highest mountain range in the Eastern Sudetes. Its highest peak is Śnieżnik $(1,425 \mathrm{~m})$. The massif lies in two countries: the north-western part in Poland and the south-eastern part, also known as Králický Sněžník (Fig. 1), in the Czech Republic. The climatic subregion of the Śnieżnik Massif is separated from other geographical-climatic units by areas of intermontane valleys and basins; it represents a distinct orographic barrier for inflowing atmospheric masses (PIASECKI and SAwIŃsKi 2009). The massif's form causes mesoscale and local deformations in the air flow. Depending on the atmospheric circulation type, the air masses flowing into the valleys adopt a direction of movement along valley axes. These valley aircurrents were termed anemo-orographic systems of air flow (JENIK 1961). In favourable conditions, these systems extend over and include valleys located on the leeward, usually northern, side of the massif (occurence of foehn winds). To date, three anemoorographic systems have been mentioned in the Śnieżnik Massif: Wilczka/Bogoryja-Czarna Woda/

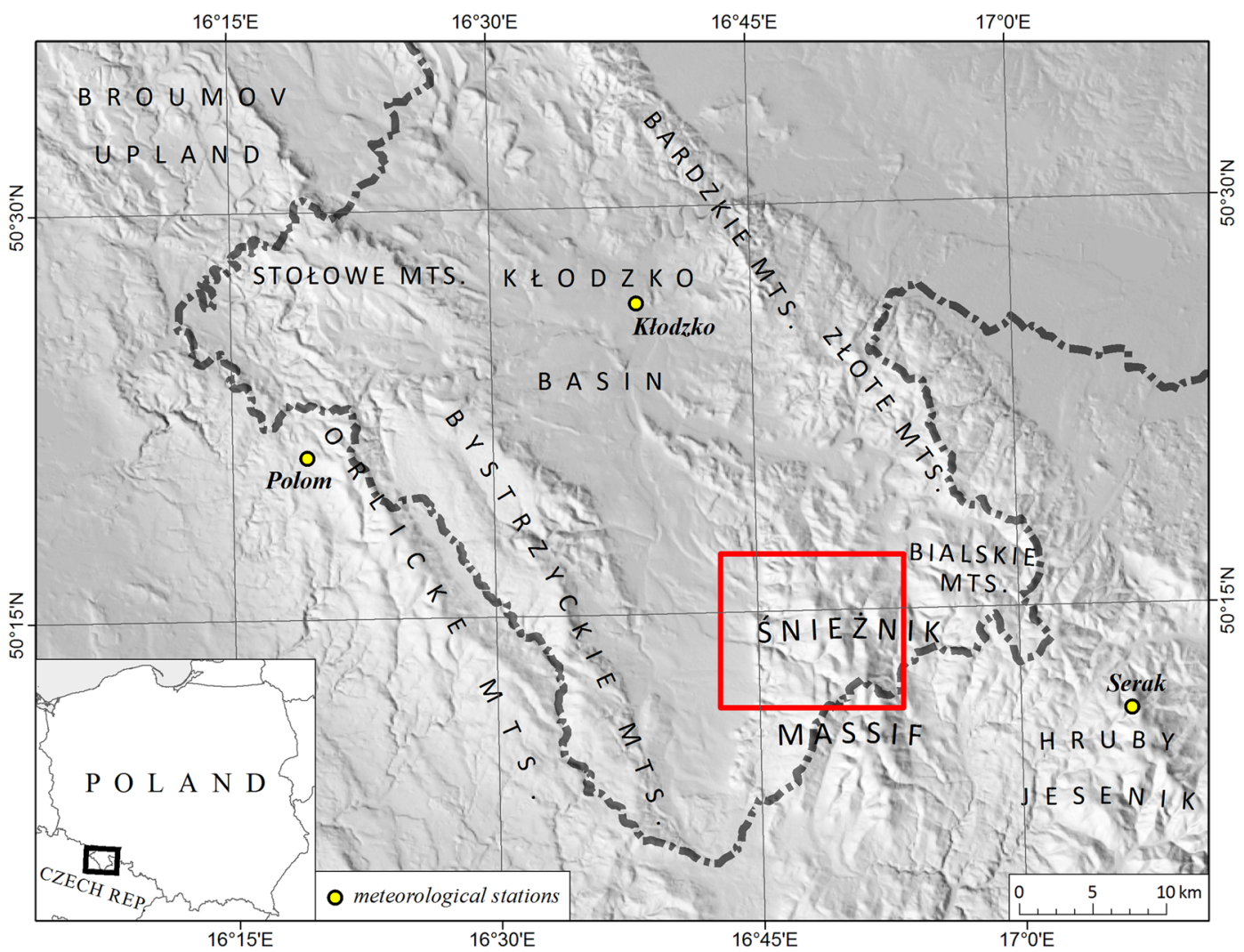

Figure 1

Position of the study area (marked by the red rectangle) 

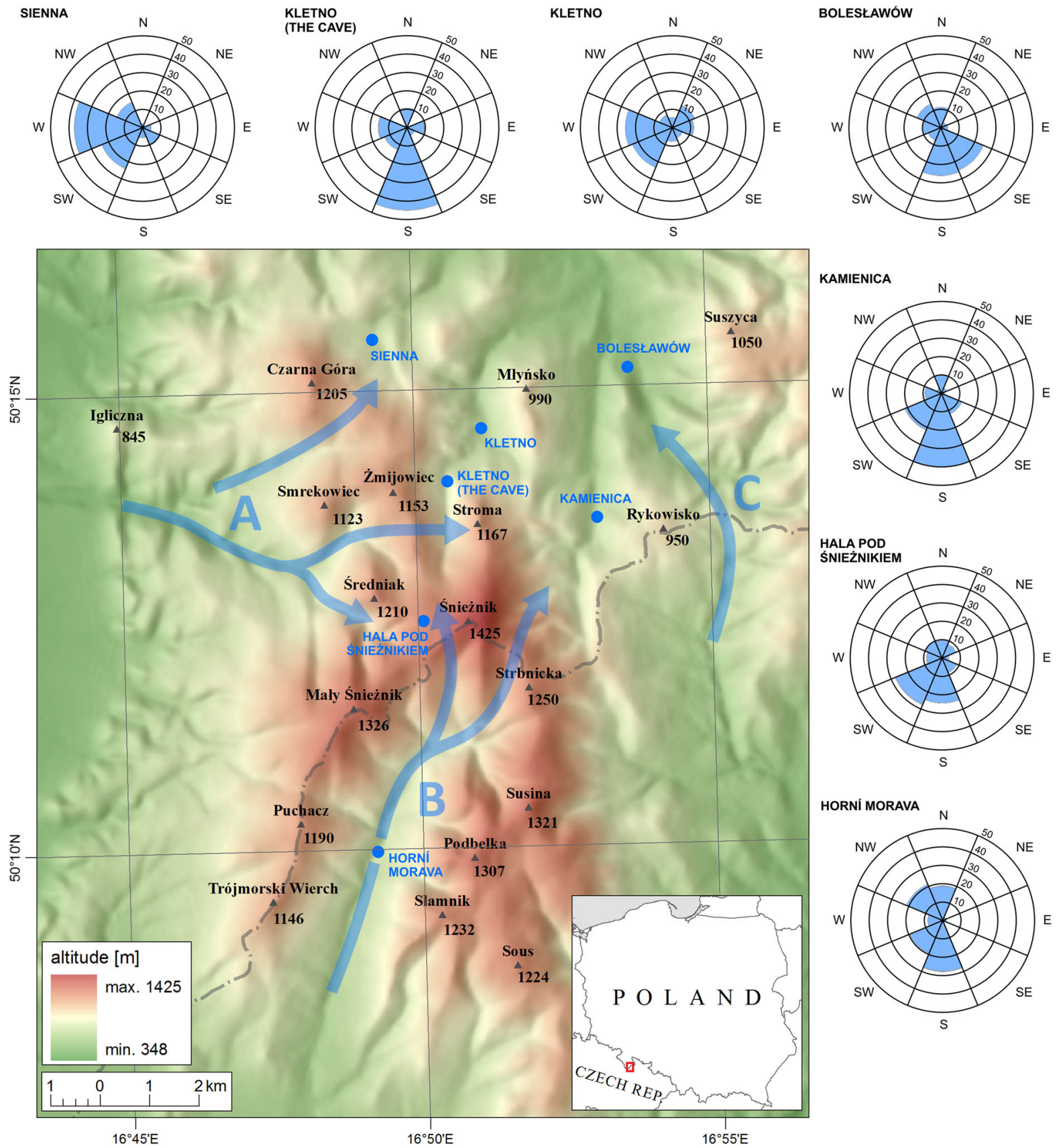

Figure 2

Mean annual frequency of wind directions in the Śnieżnik Massif in relation with local anemo-orographic wind systems: Wilczka—Pogonna (a), Velka Morava-Kleśnica, Kamienica (b), and Krupa-Morawka (c) [according to PIASECKI and SAwiŃsKi (2009)]

Kleśnica, Velka Morava-Kleśnica/Kamienica and Krupa-Morawka. Prevailing wind directions, observed by J. Kwiatkowski throughout 1973-1975, range from $\mathrm{W}$ to $\mathrm{S}$ (SSE) depending on the positioning of the measurement station (PIASECKI 1996; Piasecki and SAwiŃski 2009) (Fig. 2).

In the presented case, a rectangular research polygon was delimited in the northwestern part of the 
massif, covering an area of $120 \mathrm{sq} \mathrm{km} \mathrm{(Fig.} \mathrm{1).} \mathrm{It}$ contains the peak of Śnieżnik, the main northern ridge (peaks: Żmijowiec, Średniak, Smerkowiec, Czarna Góra), and the Wilczka and Kleśnica valleys (Fig. 3). Within the presented area, the altitude ranges from $421 \mathrm{~m}$ in the western part, to $1,425 \mathrm{~m}$ at the top of Śnieżnik. A majority of the presented area is covered by coniferous, mixed and broad-leaved forests. The one exception is the western part dominated by agricultural forms of land use.

\section{Methods}

The modelling process was carried out using WindStation 2.0.10 software, which is based on CFD solver Canyon (LOPES 2003, 2011). It solves for mass conservation, momentum conservation (Navier-
Stokes equations), energy conservation and turbulence quantities ( $\mathrm{k}-\varepsilon$ model) (Lopes 2011). The model can be initialized by point data (measurement stations) providing wind speed and direction readings from two heights above the land surface; at least one point is necessary. Values of wind velocity and direction are interpolated for each node of the computational domain using the inverse of the distance as the weighting factor (LOPES 2011). This results in an initial wind field, that subsequently undergoes further processing depending on the model settings. The final result of the modelling is a three-dimensional grid, whose nodes contain information on xyz coordinates, velocity components, direction and turbulence intensity. The first versions of WindStation, presented in 2003, were validated using data obtained from the Askervein Hill site and two test areas in Portugal (LOPES 2003). Later versions were used in a study on

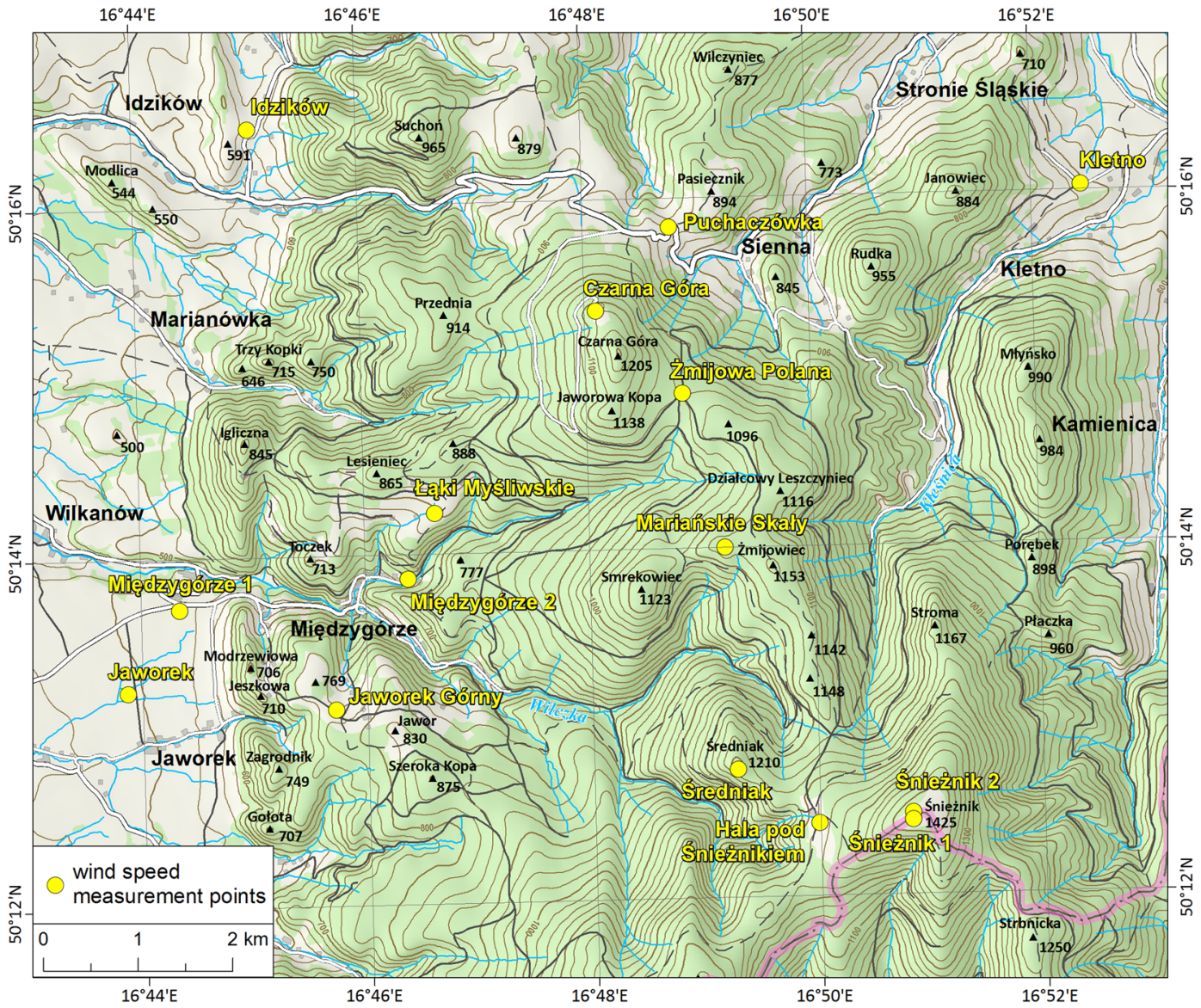

Figure 3

Distribution of wind measurement points inside the study area 

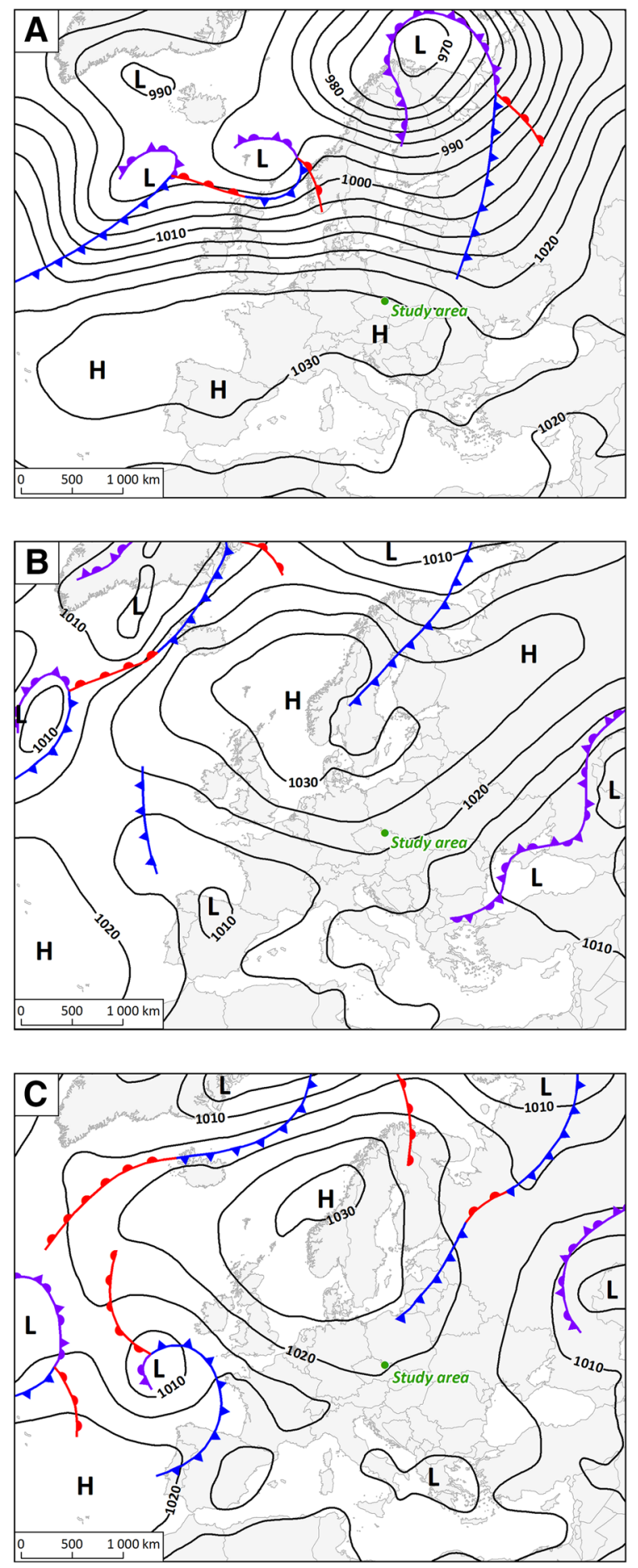

Figure 4

Atmospheric pressure field over Europe: a 26 November 2011, b 25 May 2012, c 26 May 2012 [according to the data from the Austrian Central Institute for Meteorology and Geodynamics (ZAMG)]
Figure 5

Wind speed and direction observed within study area and in Serak and Kłodzko synoptic stations during measurement time-periods: a 26 November 2011, b 25 May 2012, c 26 May 2012. The selected observation points represent the ridge area and foothills of the Śnieżnik Massif (Fig. 3; Table 1)

the estimation of wind energy resources of the El-Kef region in Tunisia (ABbes and BelHAdj 2012).

According to the circumstances mentioned in the introduction, the assumed manner of obtaining necessary input information was field measurements, conducted in short (6 or $7 \mathrm{~h}$ every day) series between November 2011 and June 2012. Due to Canyon's limitations, typical for a diagnostic model, measurements were planned for periods of constant wind direction and relatively high wind velocities (forced by horizontal pressure gradient) within and around the study area. These initial decisions concerning the choice of measurement periods were based on the analysis of the data from weather forecast web services (provided by wetteronline.de, new.meteo.pl). Following the measurements, data from the nearest synoptic stations placed in a distance of $23-37 \mathrm{~km}$ from the center of the study area (Polom, Serak, Kłodzko) (Fig. 1) were analyzed for the purpose of detecting temporal inconsistencies of wind field near the Śnieżnik Massif. Further processing of field measurements data was conducted only if these stations recorded steady wind velocity and direction during field measurements. Datasets from the mentioned stations were provided by the National Oceanic and Atmospheric Administration (ftp://ftp. ncdc.noaa.gov/pub/data/noaa/isd-lite, access date, June 10, 2012).

The foregoing procedure limited the experimental dataset to 3 days of measurements: 26 November 2011 and 25-26 May 2012. On 26 November 2011 (Fig. 4a), the Sudetes area was within the northeastern periphery of vast high-pressure area "Afra" (the names of pressure systems are quoted according to the Institute for Meteorology at the Free University of Berlin; http://www.met.fu-berlin.de/wetterpate). An inflow of maritime polar air masses occurred after the passing of the cold front connected to low "Xaver" with a centre in the northern Scandinavia. As a result, throughout the observation period, the wind conditions inside and near the study area were temporarily 

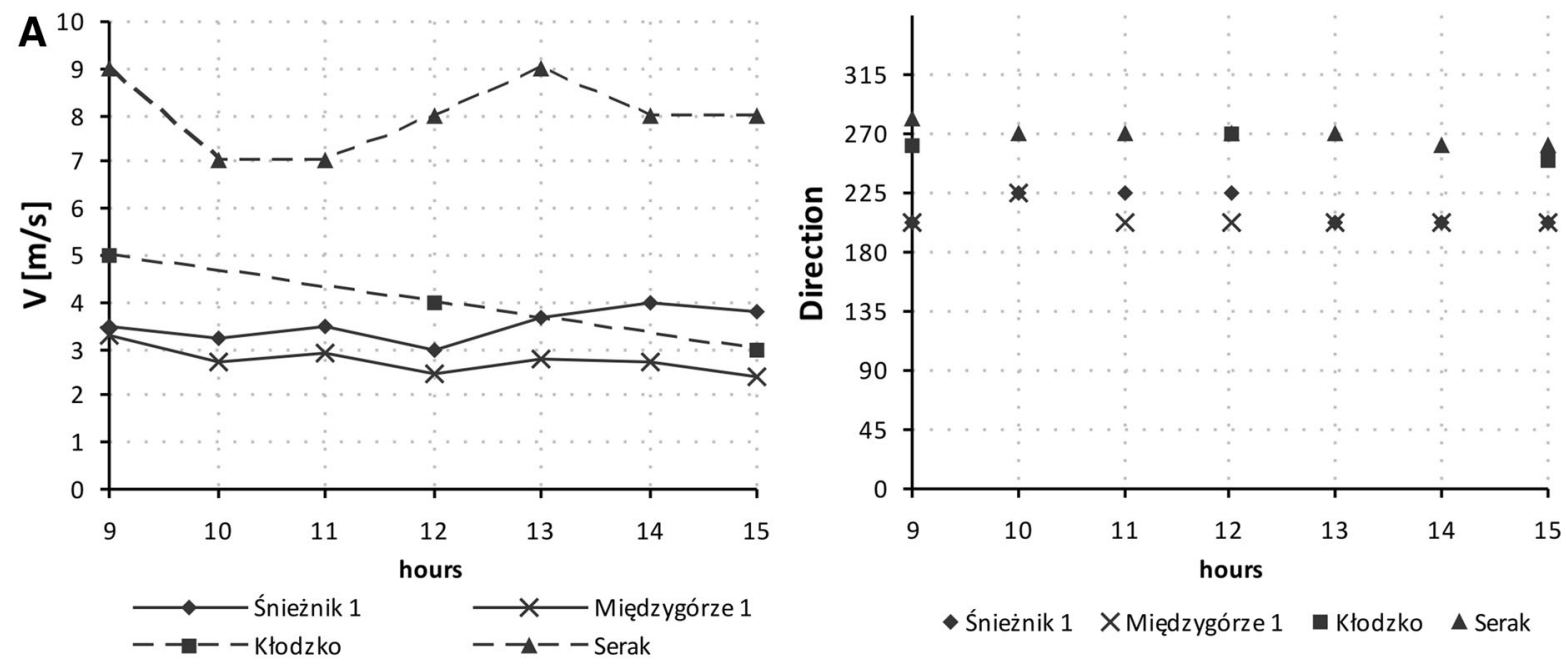

- Śnieżnik 1 XMiędzygórze 1 Kłodzko \Serak
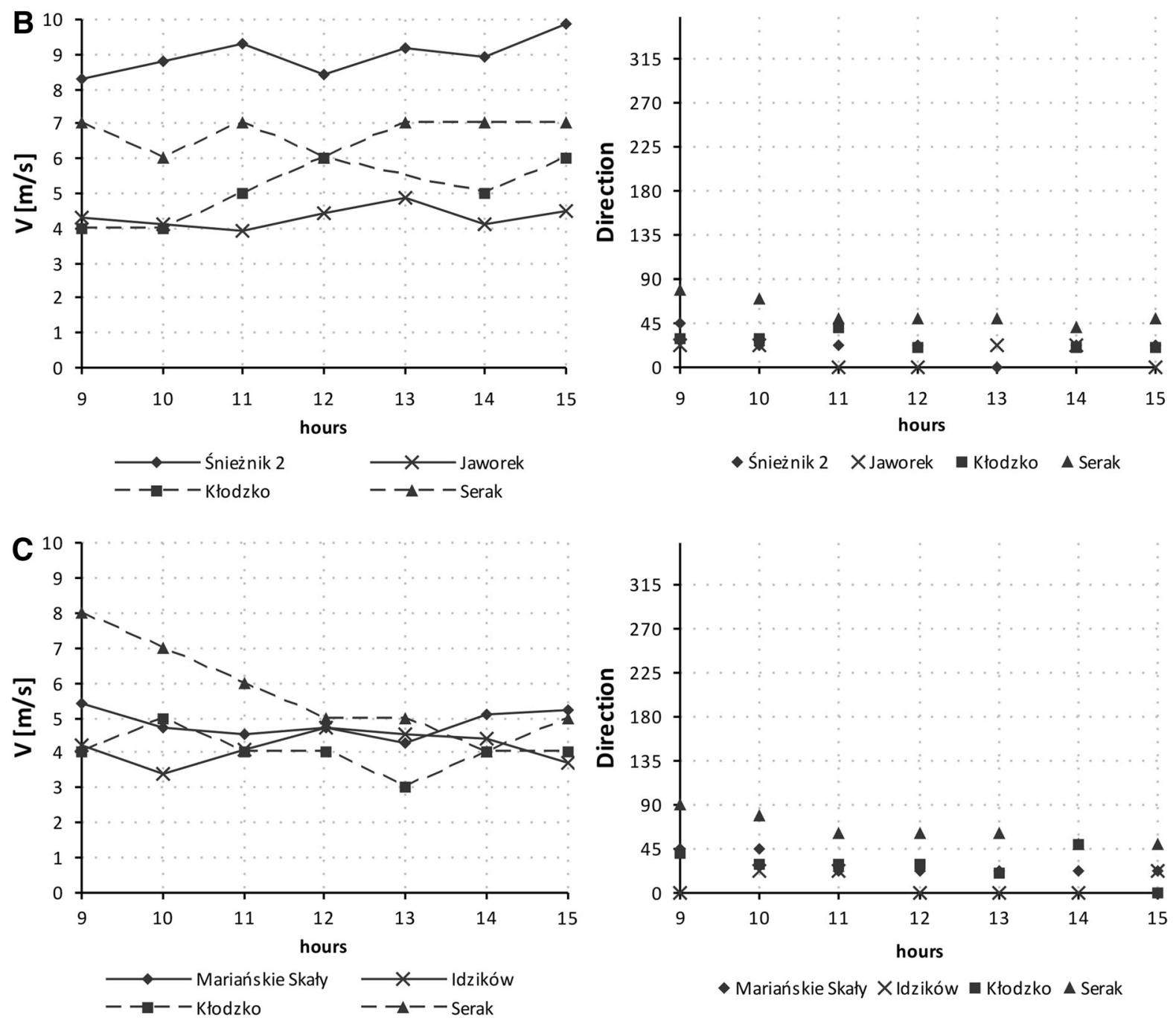

- Mariańskie Skały XIdzików @ Kłodzko \Serak 
constant. Wind direction ranged from $\mathrm{W}$ to SSW, depending on the topographic position of the observation points. Mean wind velocity ranged from $3 \mathrm{~m} / \mathrm{s}$ on the lowest altitudes to $9 \mathrm{~m} / \mathrm{s}$ in the case of stations with windward exposure placed on the highest peaks (Fig. 5a). On 25 and 26 May 2012, the study area was placed within the southern periphery of high-pressure area "Petermartin" extending above northern Europe. This situation caused an increment of horizontal pressure gradient and resulted in a moderate advection of continental polar air masses from the NE direction (Fig. 4b, c). Again, the wind conditions were temporarily constant during both observation periods. The wind direction ranged from $\mathrm{N}$ to ENE and wind velocity ranged from 4 to $10 \mathrm{~m} / \mathrm{s}$ on 25 May (Fig. 5b) and from 3 to $8 \mathrm{~m} / \mathrm{s}$ (Fig. 5c). It should be noted that on 26 May, the pressure gradient started to decrease and wind velocity values were slightly lower. Nevertheless, the general wind direction did not change.

During the measurement periods, the velocity readings were taken at a height of $2 \mathrm{~m}$ above ground level at 5-min intervals. The measurement instruments were Kaindl Windmaster 2 anemometers, for which the estimated measure error equals $\pm 4 \%$ within a range from 0.7 to $42 \mathrm{~m} / \mathrm{s}$, according to the manufacturer's specification (http://www.windtronic. com/02-e.html). The estimation of wind direction was based on the observation of banners mounted on poles at wind speed measurement points. The direction was estimated to the nearest of the 16 points of the compass, in accordance with the statement of the Commission for Instruments and Methods of Observations (CIMO) concerning simple instrumental methods of surface wind measurement (WMO 2008). Due to technical and organizational reasons, the measurements were taken in 6-h periods, starting at 9:00 and ending at 15:00.

The list of measurement points is presented in Table 1, while their spatial distribution is presented in Fig. 3. The first objective of positioning anemometers in the presented way was to record wind velocity and direction at various altitudes. The second was to conduct measurements in conditions of variable relative exposure to wind direction (windward slopes, leeward slopes, flat land). Setting measurement points inside the areas of potentially high roughness (Czarna Góra) or surrounded by topographic obstacles (Międzygórze 2) was premeditated. The author did not include data from these points as input data for the model, but used them exclusively to validate results of the modelling. The locations of

Table 1

Measurement points used in the wind velocity modelling case study

\begin{tabular}{|c|c|c|c|c|c|c|c|c|c|}
\hline \multirow[t]{3}{*}{ Measurement point } & \multirow[t]{3}{*}{$\lambda$} & \multirow[t]{3}{*}{$\varphi$} & \multirow[t]{3}{*}{ Altitude (m) } & \multicolumn{6}{|c|}{ Measurements } \\
\hline & & & & \multicolumn{2}{|c|}{ 26-11-2011 } & \multicolumn{2}{|c|}{$25-05-2012$} & \multicolumn{2}{|c|}{$26-05-2012$} \\
\hline & & & & $\begin{array}{l}\text { Mean } \\
V(\mathrm{~m} / \mathrm{s})\end{array}$ & $\begin{array}{l}\text { Mean } \\
\text { direction }\end{array}$ & $\begin{array}{l}\text { Mean } \\
V(\mathrm{~m} / \mathrm{s})\end{array}$ & $\begin{array}{l}\text { Mean } \\
\text { direction }\end{array}$ & $\begin{array}{l}\text { Mean } \\
V(\mathrm{~m} / \mathrm{s})\end{array}$ & $\begin{array}{l}\text { Mean } \\
\text { direction }\end{array}$ \\
\hline Czarna Góra & $16^{\circ} 48^{\prime} 06.3^{\prime \prime} \mathrm{E}$ & $50^{\circ} 15^{\prime} 21.9^{\prime \prime} \mathrm{N}$ & 1,122 & - & - & - & - & 2.6 & 45 \\
\hline Hala p. Śnieżnikiem & $16^{\circ} 49^{\prime} 59.6^{\prime \prime} \mathrm{E}$ & $50^{\circ} 12^{\prime} 24.9^{\prime \prime} \mathrm{N}$ & 1,229 & 3.6 & 270 & 3.5 & 0 & - & - \\
\hline Idzików & $16^{\circ} 45^{\prime} 03.2^{\prime \prime} \mathrm{E}$ & $50^{\circ} 16^{\prime} 26.9^{\prime \prime} \mathrm{N}$ & 567 & - & - & - & - & 4.1 & 0 \\
\hline Jaworek Górny & $16^{\circ} 45^{\prime} 42.7^{\prime \prime} \mathrm{E}$ & $50^{\circ} 13^{\prime} 07.5^{\prime \prime} \mathrm{N}$ & 759 & - & - & - & - & 3.6 & 7.5 \\
\hline Kletno & $16^{\circ} 52^{\prime} 26.8^{\prime \prime} \mathrm{E}$ & $50^{\circ} 16^{\prime} 01.7^{\prime \prime} \mathrm{N}$ & 611 & - & - & 4.7 & 348.8 & - & - \\
\hline Jaworek & $16^{\circ} 43^{\prime} 52.3^{\prime \prime} \mathrm{E}$ & $50^{\circ} 13^{\prime} 14.3^{\prime \prime} \mathrm{N}$ & 494 & - & - & 4.3 & 7.5 & - & - \\
\hline Łąki Myśliwskie & $16^{\circ} 46^{\prime} 37.6^{\prime \prime} \mathrm{E}$ & $50^{\circ} 14^{\prime} 14.0^{\prime \prime} \mathrm{N}$ & 795 & 1.3 & 247.5 & - & - & 2.8 & 45 \\
\hline Mariańskie Skały & $16^{\circ} 49^{\prime} 12.4^{\prime \prime} \mathrm{E}$ & $50^{\circ} 14^{\prime} 00.1^{\prime \prime} \mathrm{N}$ & 1,133 & 3.9 & 225 & - & - & 4.8 & 22.5 \\
\hline Międzygórze 1 & $16^{\circ} 44^{\prime} 20.8^{\prime \prime} \mathrm{E}$ & $50^{\circ} 13^{\prime} 42.6^{\prime \prime} \mathrm{N}$ & 520 & 2.8 & 202.5 & 2.2 & 0 & - & - \\
\hline Międzygórze 2 & $16^{\circ} 46^{\prime} 23.1^{\prime \prime} \mathrm{E}$ & $50^{\circ} 13^{\prime} 51.8^{\prime \prime} \mathrm{N}$ & 636 & - & - & - & - & 1.7 & 191.3 \\
\hline Puchaczówka & $16^{\circ} 48^{\prime} 46.4^{\prime \prime} \mathrm{E}$ & $50^{\circ} 15^{\prime} 50.3^{\prime \prime} \mathrm{N}$ & 868 & - & - & 3.3 & 45 & - & - \\
\hline Śnieżnik 1 & $16^{\circ} 50^{\prime} 49.5^{\prime \prime} \mathrm{E}$ & $50^{\circ} 12^{\prime} 25.5^{\prime \prime} \mathrm{N}$ & 1,424 & 3.5 & 213.8 & - & - & - & - \\
\hline Śnieżnik 2 & $16^{\circ} 50^{\prime} 49.6^{\prime \prime} \mathrm{E}$ & $50^{\circ} 12^{\prime} 28.1^{\prime \prime} \mathrm{N}$ & 1,423 & - & - & 9.0 & 22.5 & - & - \\
\hline Średniak & $16^{\circ} 49^{\prime} 16.7^{\prime \prime} \mathrm{E}$ & $50^{\circ} 12^{\prime} 43.9^{\prime \prime} \mathrm{N}$ & 1,199 & 5.5 & 247.5 & 4.2 & 22.5 & - & - \\
\hline Żmijowa Polana & $16^{\circ} 48^{\prime} 51.4^{\prime \prime} \mathrm{E}$ & $50^{\circ} 14^{\prime} 53.1^{\prime \prime} \mathrm{N}$ & 1,047 & 2.8 & 202.5 & - & - & 3.2 & 22.5 \\
\hline
\end{tabular}




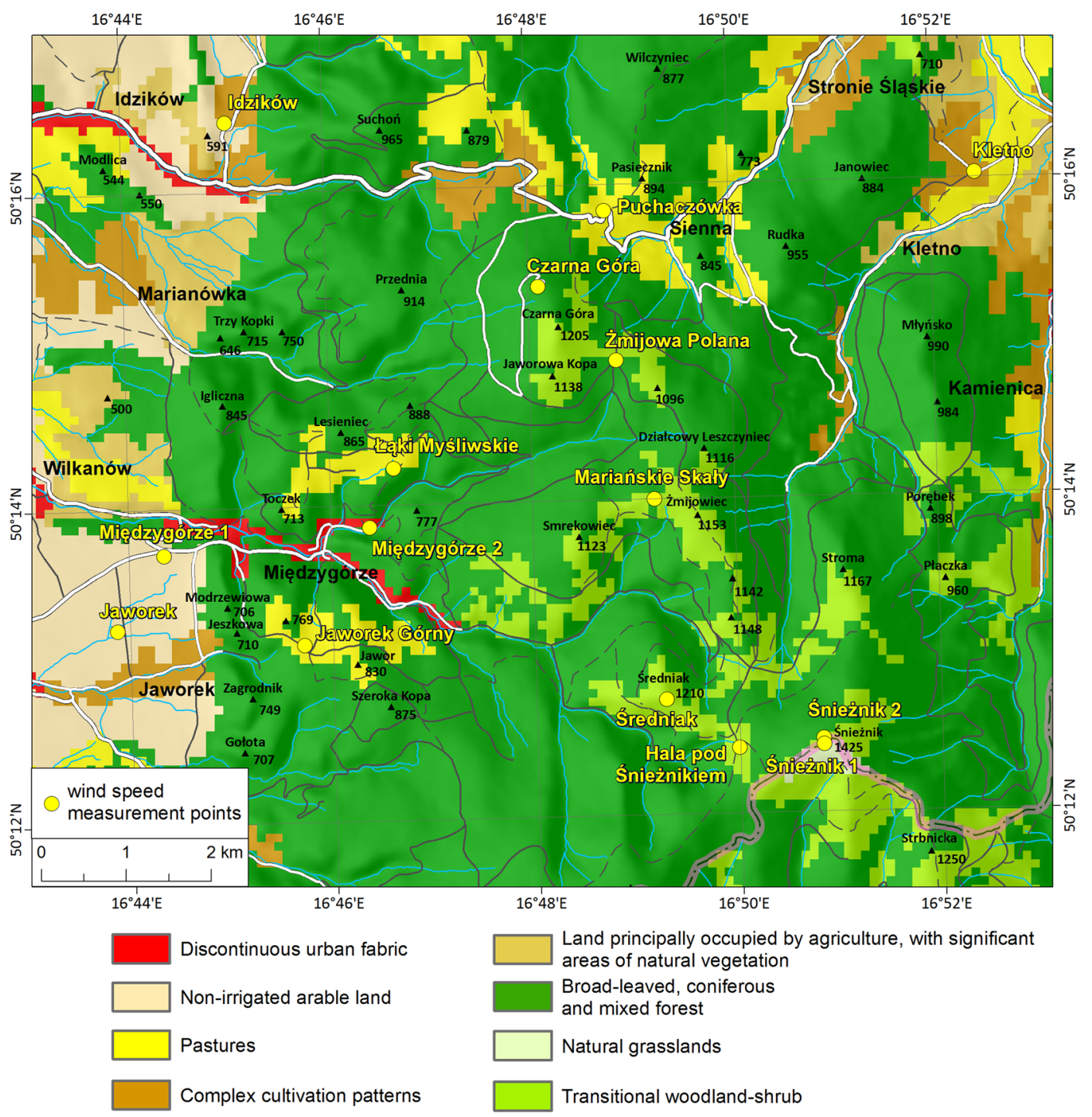

Figure 6

Land use of the study area based on Corine Land Cover 2006 raster version

other points were also carefully selected following field reconnaissance to minimize the potential impact of topographic obstacles-the position of every measurement point was determined by the actual topographic situation, not by remote sensing land-use data.

The next step of data pre-processing involved a reading-based calculation of hourly mean velocity values and prevailing directions in order to use them as an input data to the model. Information about wind conditions in the upper parts of the atmospheric boundary layer was based on the upper air soundings performed in stations nearest to the study area: Praha-Libus, Prostejov and Wrocław. The results of the soundings were provided by the Department of Atmospheric Science at the University of Wyoming (http://www.weather.uwyo.edu/ upperair/sounding.html, access date: June 10, 2012).

The second part of the input dataset contained information on land surface (elevation and roughness length) and was based on remote sensing data. Two digital elevation models were used: Global Land Survey Digital Elevation Model (GLSDEM) and Digital Terrain Elevation Data (DTED) Level 2. The 


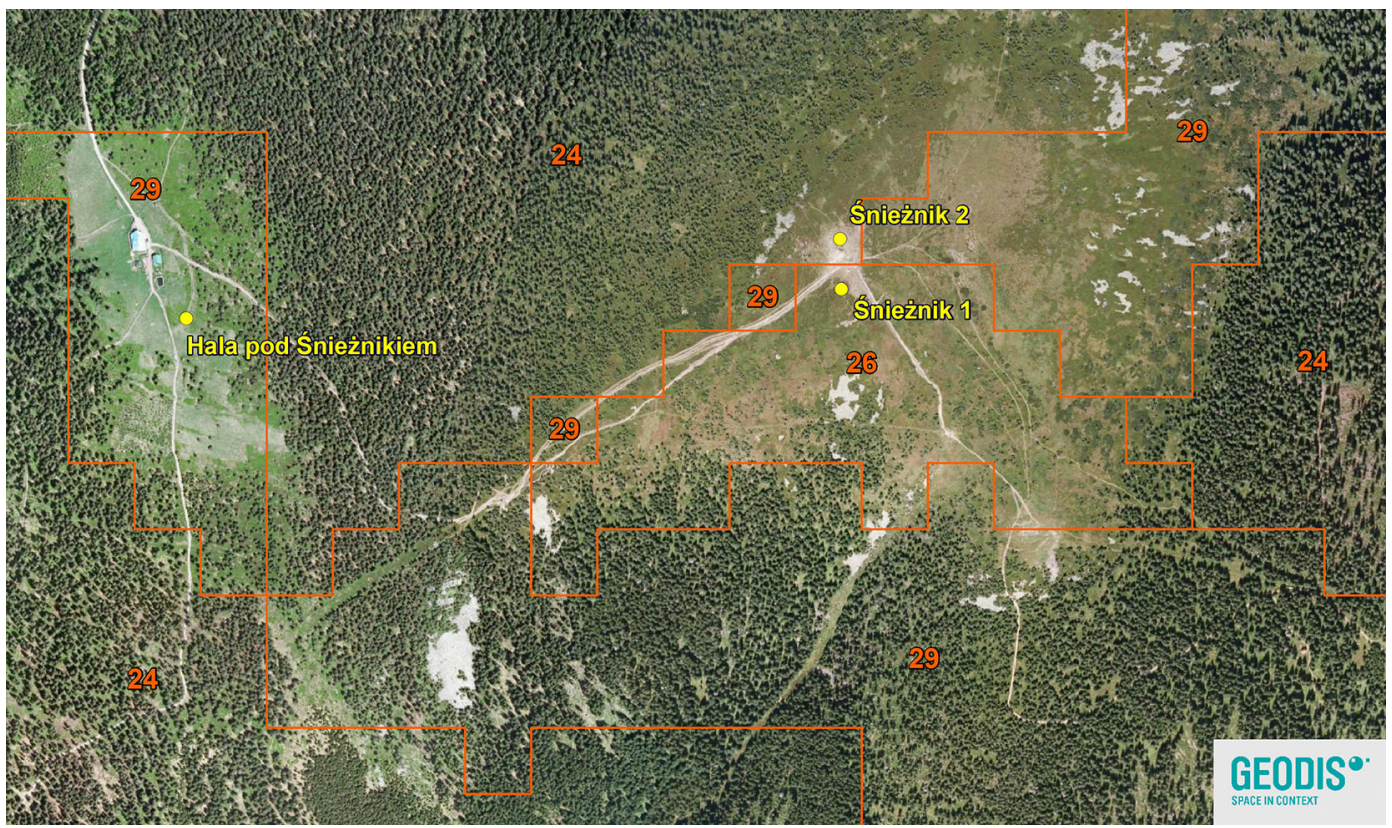

Figure 7

Example of discordances between CLC 2006 classification results and actual land use on the peak of Śnieżnik. CLC 2006 polygons are indicated by numbers: 24 coniferous forest, 26 natural grasslands, 29 transitional woodland-shrub (orthophotomap source: GEODIS BRNO, spol. s.r.o.)

\section{Table 2}

Roughness length classes based on Corine Land Cover 2006

\begin{tabular}{ll}
\hline Land use type & $z_{\mathrm{o}}(\mathrm{m})$ \\
\hline Discontinuous urban fabric & 0.6 \\
Non-irrigated arable land & 0.03 \\
Pastures & 0.03 \\
Land principally occupied by agriculture with significant & 0.1 \\
$\quad$ areas of natural vegetation & \\
Complex cultivation patterns & 0.1 \\
Broad-leaved, coniferous or mixed forest & 1.4 \\
Transitional woodland-shrub (sparse coniferous forest) & 0.4 \\
Natural grassland & 0.05 \\
\hline
\end{tabular}

former is a $90-\mathrm{m}$ resolution model, developed by USGS (United States Geological Survey) and provided by GLCF (Global Land Cover Facility http:// www.glcf.umiacs.umd.edu/data/glsdem, access date: 13 March 2012). The latter is a 30-m resolution model, based on military 1:50,000 topographical maps, and was used for comparison. Roughness length information was based on Corine Land Cover 2006 (version 15) 100-m resolution raster dataset, provided by the European Environmental Agency (EEA, http://www.eea.europa.eu/data-and-maps/data/ corine-land-cover-2006-raster-1, access date: 13 March 2012). The land use map of the study area based on the CLC 2006 data is presented in Fig. 6. To avoid discordances which could affect the model's performance, CLC 2006 data were compared to Polish and Czech orthophotomaps (provided by GEODIS BRNO, spol. s.r.o. and geoportal.gov.pl web service) and, where necessary, corrected. The biggest discordances manifested themselves in the upper tree line (example on Fig. 7) and were probably a consequence of differences in spectral response caused by terrain parameters such as aspect or slope. In order to detect the impact of corrections on the model's performance, the subsequent simulations were conducted using original and corrected roughness data in an alternating manner. Roughness length assignment was mainly based on the Finnish Wind Atlas classification (http://www.tuuliatlas.fi/ modelling/mallinnus_3.html, access date: March 15th, 2012). In one problematic case (CLC class "transitional woodland-shrub" is not included in the Finnish Wind Atlas) an assignment problem was also considered according to the proceedings of European Wind Energy Conference 2007 (Silva et al. 2007). 
Table 3

Error measures used in evaluation of overall wind field modelling results

\begin{tabular}{|c|c|c|c|}
\hline Variable & Error measure & Equation & Remarks \\
\hline \multirow[t]{3}{*}{$\begin{array}{l}\text { Wind } \\
\text { velocity }\end{array}$} & Bias error (EMERY et al. 2001) & $B_{\mathrm{v}}=\frac{1}{N} \sum_{i=1}^{N}\left(v_{\mathrm{m}}-v_{\mathrm{o}}\right)$ & $\begin{array}{l}v_{\mathrm{m}}-\text { modelled wind velocity; } v_{0} \text { - observed wind } \\
\text { velocity }\end{array}$ \\
\hline & $\begin{array}{l}\text { Root mean square error } \\
\quad \text { (EMERY et al. 2001) }\end{array}$ & $\mathrm{RMSE}_{\mathrm{v}}=\sqrt{\frac{1}{N} \sum_{i=1}^{N}\left(v_{\mathrm{m}}-v_{\mathrm{o}}\right)^{2}}$ & $\begin{array}{l}v_{\mathrm{m}}-\text { modelled wind velocity; } v_{\mathrm{o}} \text {-observed wind } \\
\text { velocity }\end{array}$ \\
\hline & $\begin{array}{l}\text { Index of wind speed (Lopes } \\
\text { 2003) }\end{array}$ & $I_{\mathrm{v}}=\frac{1}{N} \sum_{i=1}^{N} 100 e^{\left[-0.692\left(\frac{v_{2}}{v_{2}}-1\right)\right]}$ & $\begin{array}{l}v_{1}, v_{2} \text { - observed and simulated velocities or vice } \\
\text { versa, with } v_{1}>v_{2}\end{array}$ \\
\hline \multirow[t]{2}{*}{$\begin{array}{l}\text { Wind } \\
\text { direction }\end{array}$} & Mean absolute error & $\mathrm{MAE}_{\mathrm{dir}}=\frac{1}{N} \sum_{i=1}^{N}\left[\arccos \left(\cos \left(\phi_{\mathrm{m}}-\phi_{\mathrm{o}}\right)\right)\right]$ & $\begin{array}{l}\phi_{\mathrm{m}} \text {-modelled wind direction; } \phi_{\mathrm{o}} \text {-observed wind } \\
\text { direction }\end{array}$ \\
\hline & $\begin{array}{l}\text { Index of wind direction } \\
\quad \text { (LOPES 2003) }\end{array}$ & $I_{\mathrm{dir}}=\frac{1}{N} \sum_{i=1}^{N}\left[50+50 \cos \left(\phi_{\mathrm{m}}-\phi_{\mathrm{o}}\right)\right]$ & $\begin{array}{l}\phi_{\mathrm{m}} \text {-modelled wind direction; } \phi_{\mathrm{o}} \text {-observed wind } \\
\text { direction }\end{array}$ \\
\hline
\end{tabular}
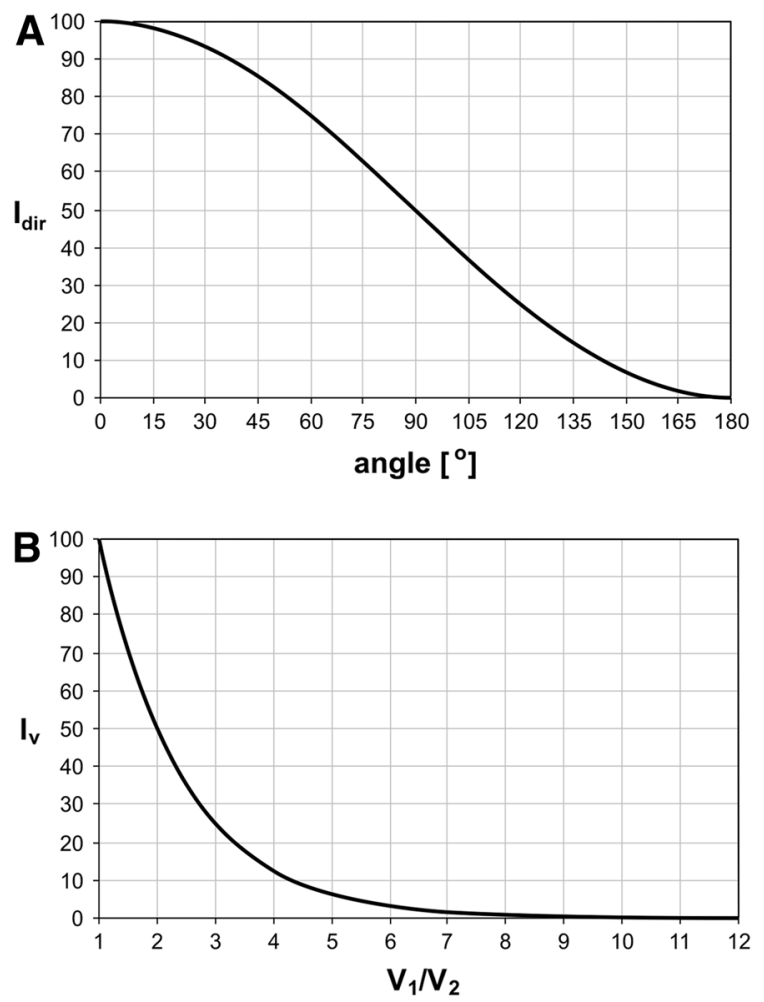

Figure 8

a Relationship between direction mismatch and index of wind direction $\left(I_{\mathrm{dir}}\right)$, b relationship between velocity mismatch and index of wind velocity $\left(I_{\mathrm{v}}\right)$

The final assignment results are presented in Table 2 . Both elevation and roughness data were preprocessed in ArcInfo software and exported to ASCII format, required by WindStation.

Modelling was performed using various resolutions of the calculation domain (100 and $250 \mathrm{~m}$ ) and various input data (elevation model, constant-
$0.05 \mathrm{~m}$ or CLC 2006 based-on roughness). The model top was defined as $2,500 \mathrm{~m}$; this value was a minimum for the model to perform properly. Finally, the computational grid had $146 \times 126 \times 20$ nodes $(100-\mathrm{m}$ resolution $)$ or $59 \times 51 \times 20$ nodes $(250-\mathrm{m}$ resolution). The first node was placed at a height of $4 \mathrm{~m}$. To enable comparison of results with previous studies (LOPES 2003), an assumption of neutral atmospheric stability was made. Thus, the further conclusions of the study do not apply to the modelling in stable or unstable atmosphere.

Raw output data were exported to ArcInfo, converted to a shapefile vector format and subsequently converted to a raster format using the spline interpolation method.

In order to evaluate the model's performance, a modified leave-one-out cross-validation was executed. For every repetition of the model's performance, the original wind velocity/direction dataset was divided into two subdatasets: the input (training) dataset and the validation dataset. In theory, the data obtained from seven observational sites working at the same time, allowed for the creation of 119 different combinations of input datasets (containing from 2 up to 6 points) per hour. However, due to the limited time and computer resources, it would be impracticable to use all of them (the study would have ended after 5,712 runs of the model). Instead, it was decided that 20 different training datasets would be used per every observational hour. It was assumed that the half of these sets had to contain at least five measurement points while the rest included at least two measurement points. Within the aforesaid conditions, the datasets were chosen randomly as the 


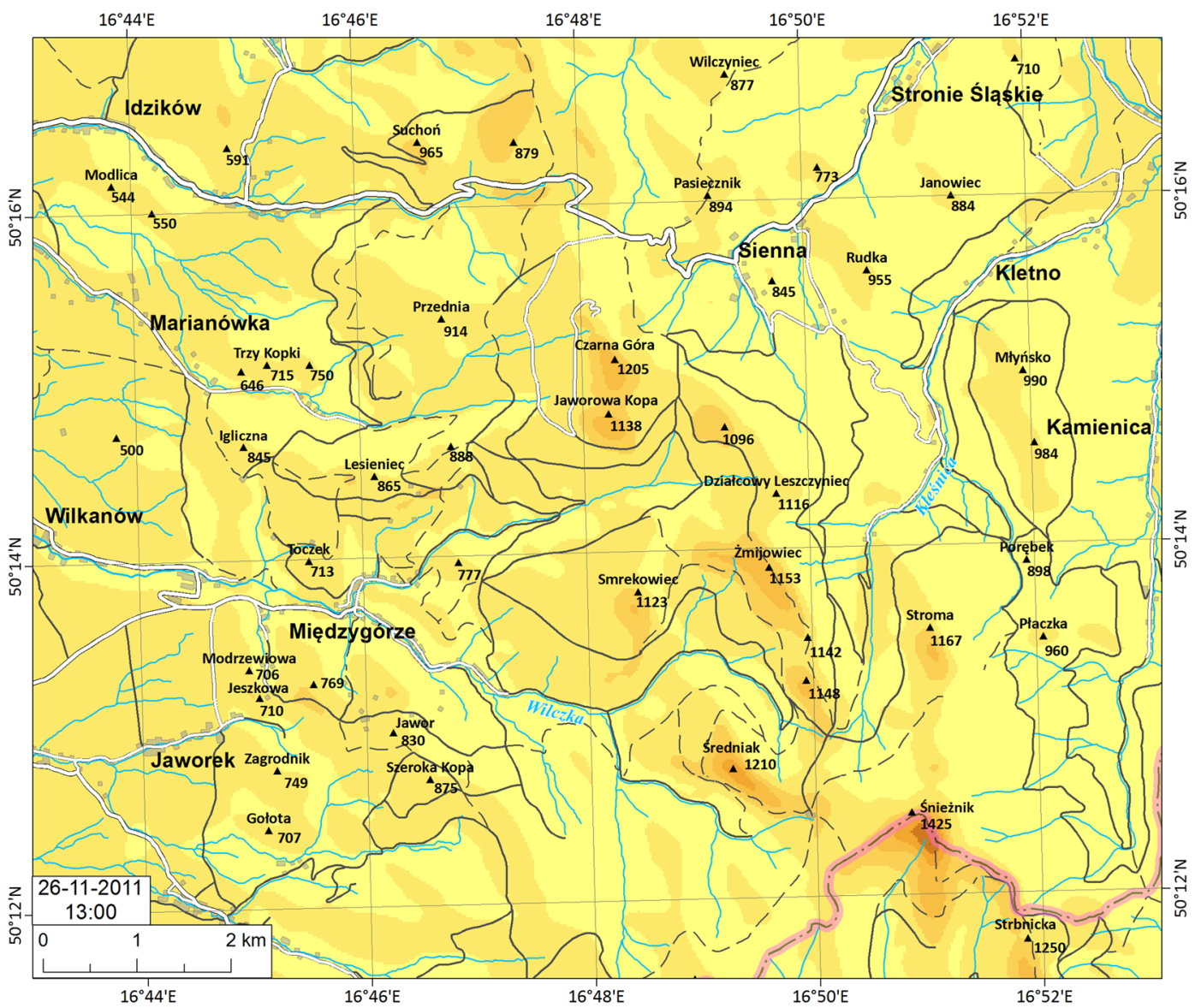

Mean modelled wind speed (height: $2 \mathrm{~m}$ ) [m/s]

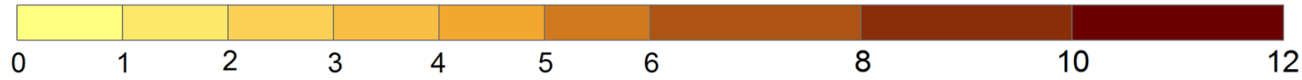

Figure 9

Spatial distribution of mean modelled wind velocity (26 November 2011; 13:00). The values were calculated from the results of 20 simulations based on various combinations of the input measurement points (containing at least two points). The model's setup included roughness length information derived from CLC 2006

deliberate choice of training datasets could affect the results of the experiment. As a result, 120 runs of Canyon were performed for every day of measurements and for every specific model setup. This enabled a calculation of the following performance indices: velocity Bias $\left(B_{\mathrm{v}}\right)$, root mean square error of velocity $\left(\mathrm{RMSE}_{\mathrm{v}}\right)$, index of wind speed $\left(I_{\mathrm{v}}\right)$ direction mean absolute error $\left(\mathrm{MAE}_{\mathrm{dir}}\right)$ and index of wind direction $\left(I_{\mathrm{dir}}\right)$. The equations for the indices are presented in Table 3 . Figure 8 contains additional plots for $I_{\mathrm{v}}$ and $I_{\mathrm{dir}}$ which were used for comparison of the model's performance with Poiares and Trevim sites (LOPES 2003).
The next step involved the execution of Student's $t$ test for paired samples in order to determinate statistically whether the changes of the resolution, roughness or DEM setup affect significantly the results of the modelling. Finally, fields of the mean velocity and the velocity range were calculated for selected hours and model setups. This calculation was conducted using the focal statistics tools; it was based on the raster representations of the wind velocity at a height of $2 \mathrm{~m}$ above ground level, created during the consecutive runs of the model (described in the previous paragraph). The main purpose of the aforementioned calculation was to present 


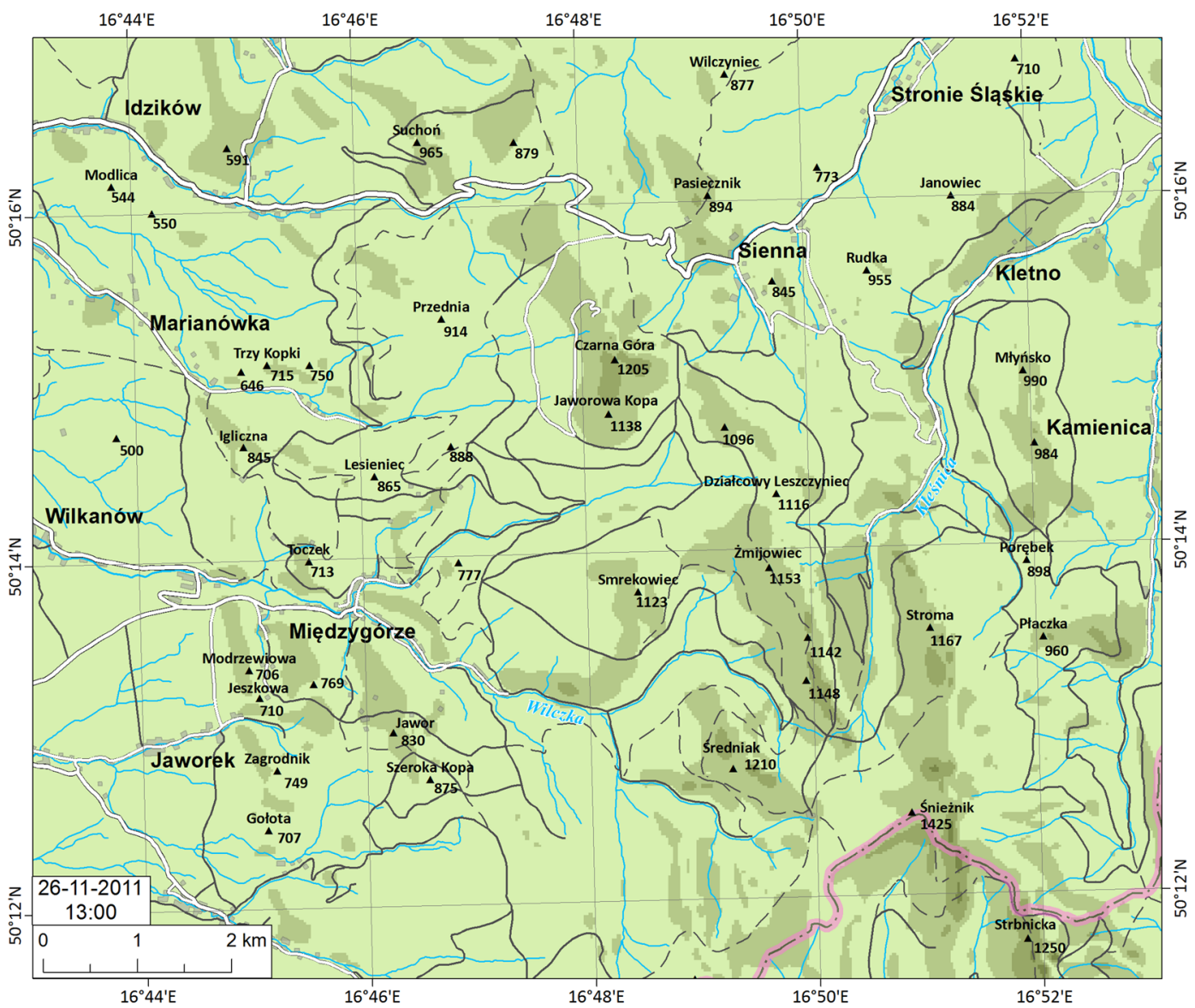

Range of modelled wind speed (height: $2 \mathrm{~m}$ ) [m/s]

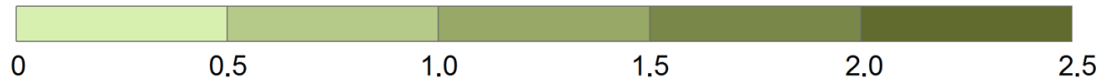

Figure 10

Spatial distribution of modelled wind velocity range (26 November $2011 ; 13: 00)$. The values $\left(V_{\max }-V_{\min }\right)$ were calculated from the results of 20 simulations based on various combinations of the input measurement points (containing at least two points). The model's setup included roughness length information derived from CLC 2006

graphically some examples of the spatial variability of the modelled wind velocity field (mean velocity) and differences in the modelled wind field which occur if various sets of input measurement points are used in the modelling (velocity range, defined as $\left.V_{\max }-V_{\min }\right)$.

\section{Results}

As a final result of the modelling and data postprocessing, it was possible to present graphically the simulated wind field in the study area. The examples of maps displaying mean modelled wind velocity and modelled velocity range are given in Figs. 9, 10 (26 November 2011; 13:00) and Figs. 11, 12, 13 and 14 (26 May 2012; 13:00). Images generated for 25 May were very similar to those for the next day, due to the same prevailing wind direction. As is noticeable, in both presented episodes, the highest wind velocity values at the considered height of $2 \mathrm{~m}$ are typical for peaks and ridges above $1,000 \mathrm{~m}$ a.s.l. (Śnieżnik, Średniak, Żmijowec, Czarna Góra and Jaworowa Kopa). Relatively high velocities can also be noticed on pastures located on windward slopes (example: pastures placed south from Międzygórze on Fig. 11) 


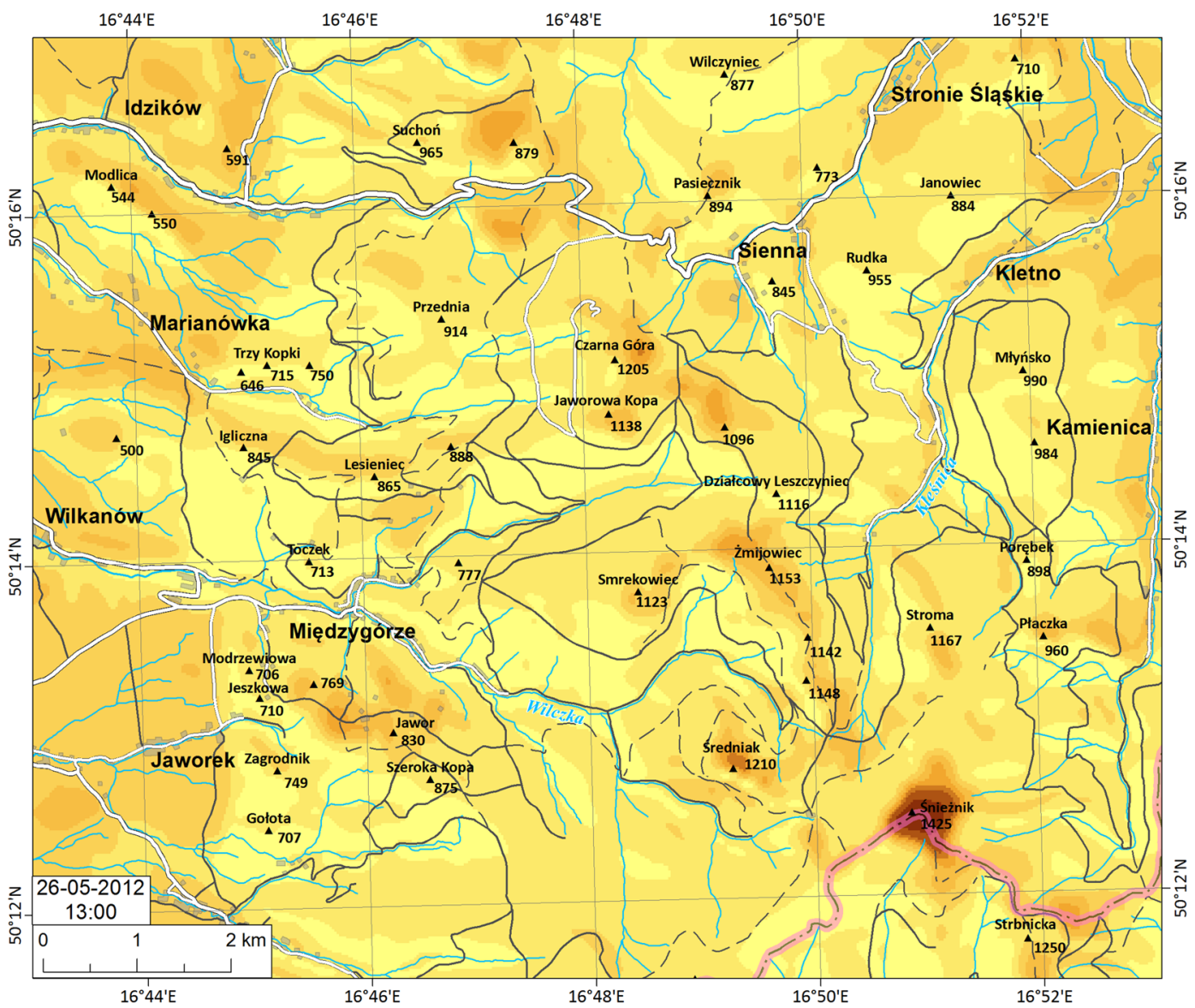

Mean modelled wind speed (height: $2 \mathrm{~m}$ ) [m/s]

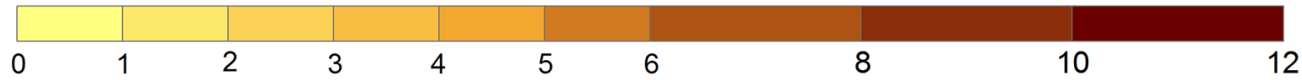

Figure 11

Spatial distribution of mean modelled wind velocity (26 May 2012; 13:00). The values were calculated from the results of 20 simulations based on various combinations of the input measurement points (containing at least two points). The model's setup included roughness length information derived from CLC 2006

and in windward areas at low altitudes, which are mainly arable lands.

The spatial distribution of mean wind velocity tends to vary due to differences between the main wind directions (WSW on 26 November and NNE on 25 and 26 May). The model of the November episode (Fig. 9) presents a very well developed western windward area of higher velocities and the eastern leeward area, where wind velocity is significantly lower. On the other hand, in the situation observed on 26 May (Fig. 11) this division is more explicit. The main reason for this difference is the relation of the direction of atmospheric circulation to the orientation of the main convex terrain forms (mountain ridges) almost perpendicular on 26 November and slantwise on 26 May. Another noteworthy aspect is the changes in spatial variability of the modelled velocity rangesimulations for the May episode are significantly more diverse in the area of western foothills of the massif (Fig. 12), than in case of the November episode (Fig. 10). Nevertheless, within the greater part of study area, velocity range does not exceed $1.0 \mathrm{~m} / \mathrm{s}$. The aforementioned remarks relate to the results of modelling with the use of input variable roughness information. The assumption of uniform roughness completely changes the wind field image (Figs. 13, 


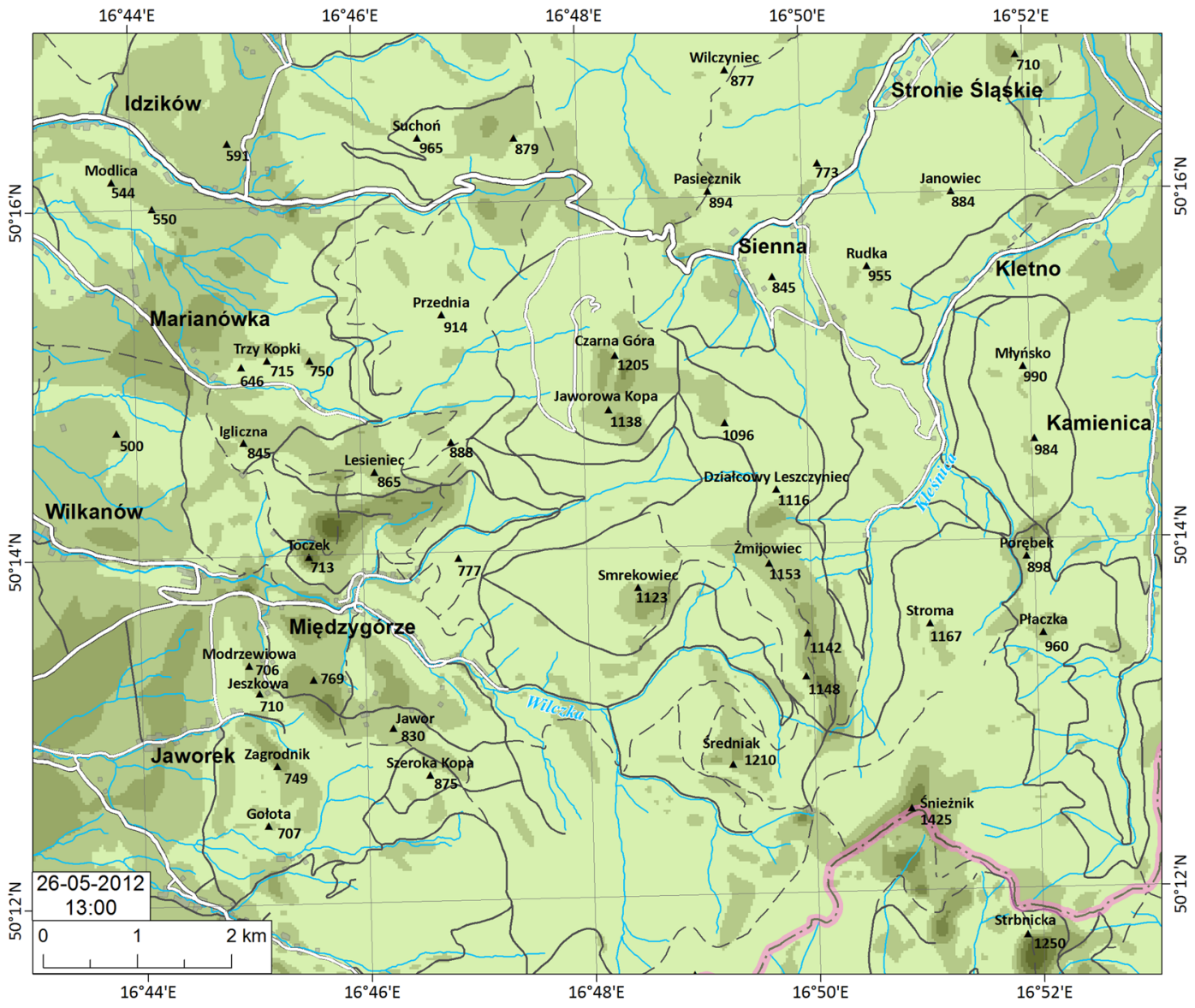

Range of modelled wind speed (height: $2 \mathrm{~m}$ ) [m/s]

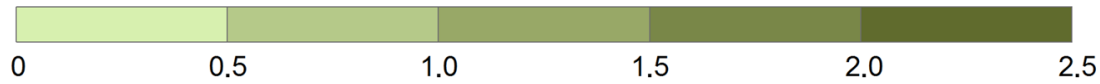

Figure 12

Spatial distribution of modelled wind velocity range (26 May 2012; 13:00). The values $\left(V_{\max }-V_{\min }\right)$ were calculated from results of 20 simulations based on various combinations of the input measurement points (containing at least two points). The model's setup included roughness length information derived from CLC 2006

14) — it becomes a strict reflection of the local relief and its morphometric parameters. It should be noted that in this case the values of velocity range are higher as compared to the results achieved by the model's performance using CLC 2006 roughness (Fig. 12).

Lowering the spatial resolution of the model produces a less-detailed wind-field simulation (Fig. 15). Differences can be observed in the whole area, although a tendency to estimate lower velocities above isolated peaks and ridges is the most evidentthe area near the top of Średniak seems to be a good example.
The analysis of model performance indices reveals that, within the given domain resolution, using different DEMs does not change significantly the accuracy of the modelled wind velocity field. The DTED model provides slightly better index values, however GLS DEM may be successfully used instead. Including the roughness length information (derived from CLC 2006), significantly improves accuracy of the model in case of a $100 \mathrm{~m}$ resolution. It is expressed by decreasing $\mathrm{RMSE}_{\mathrm{v}}$ and increasing $I_{\mathrm{v}}$ values (Fig. 16) -respectively to $\mathrm{RMSE}_{\mathrm{v}}=1.1 \mathrm{~m} /$ $\mathrm{s}$ and $I_{\mathrm{v}}=80$ for GLSDEM, for DTED RMSE $\mathrm{v}_{\mathrm{v}}=$ $1.0 \mathrm{~m} / \mathrm{s}$ and $I_{\mathrm{v}}=82$. However, including the same 


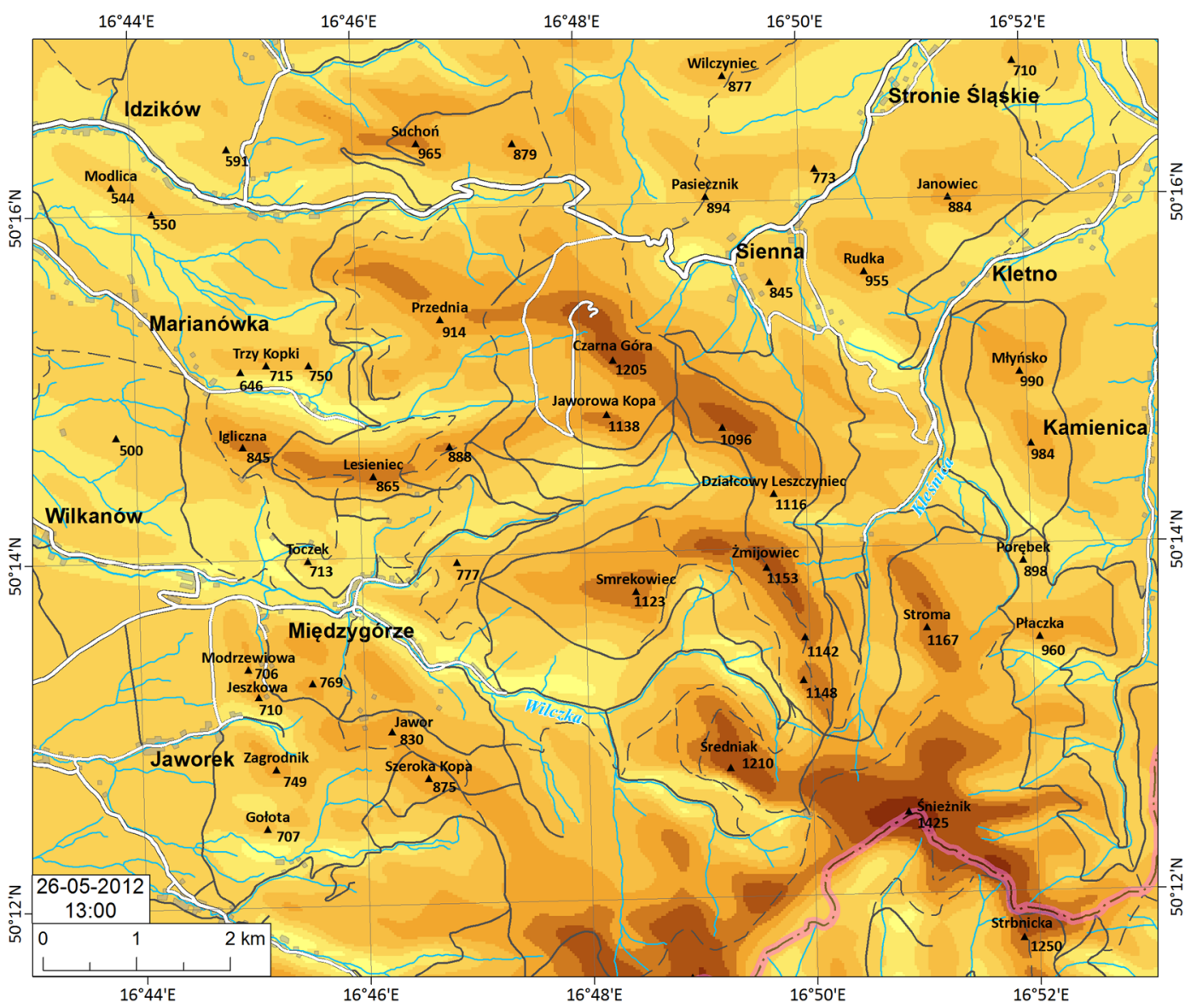

Mean modelled wind speed (height: $2 \mathrm{~m}$ ) [m/s]

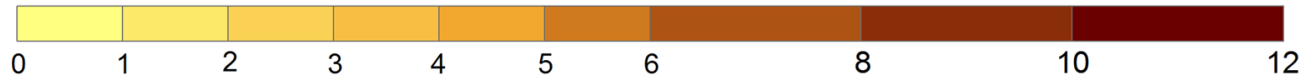

Figure 13

Spatial distribution of mean modelled wind velocity (26 May 2012; 13:00). The values were calculated from the results of 20 simulations based on various combinations of the input measurement points (containing at least two points). A constant roughness length $\left(z_{0}=0.05 \mathrm{~m}\right)$ was assumed

information in a lower (250-m) model resolution causes a slight decrement of both $\mathrm{RMSE}_{\mathrm{v}}$ and $I_{\mathrm{v}}$. This indicates that the mean absolute error is decreased, but simultaneously the model's relative mean performance is also affected. This is probably a consequence of relatively worse results for locations characterized by low wind velocity (Międzygórze 2) or in locations surrounded by complex roughness patterns which could not be properly presented in a resolution lower than $100 \mathrm{~m}$ (Mariańskie Skały, Puchaczówka). Significant changes of $B_{\mathrm{v}}$ values (Fig. 16) are also evident. In the presented case, the model tends to overestimate velocity if a constant (but relatively low) value of roughness is set. It also tends to underestimate velocity if CLC 2006 roughness information is added (the underestimation is greater in coarser domain resolution). According to the modelled wind direction, changes of input data configuration and resolution did not affect markedly the accuracy of the model. Mean $\mathrm{MAE}_{\mathrm{dir}}$ values ranged from $28^{\circ}$ to $32^{\circ}$ (Fig. 16).

A more detailed insight into performance indices' values, calculated for particular measurement points and pertaining to the domain resolution and the input data, is presented in Tables 4 and 5. Differences between $B_{\mathrm{v}}$ and $\mathrm{RMSE}_{\mathrm{v}}$ values, calculated for a 


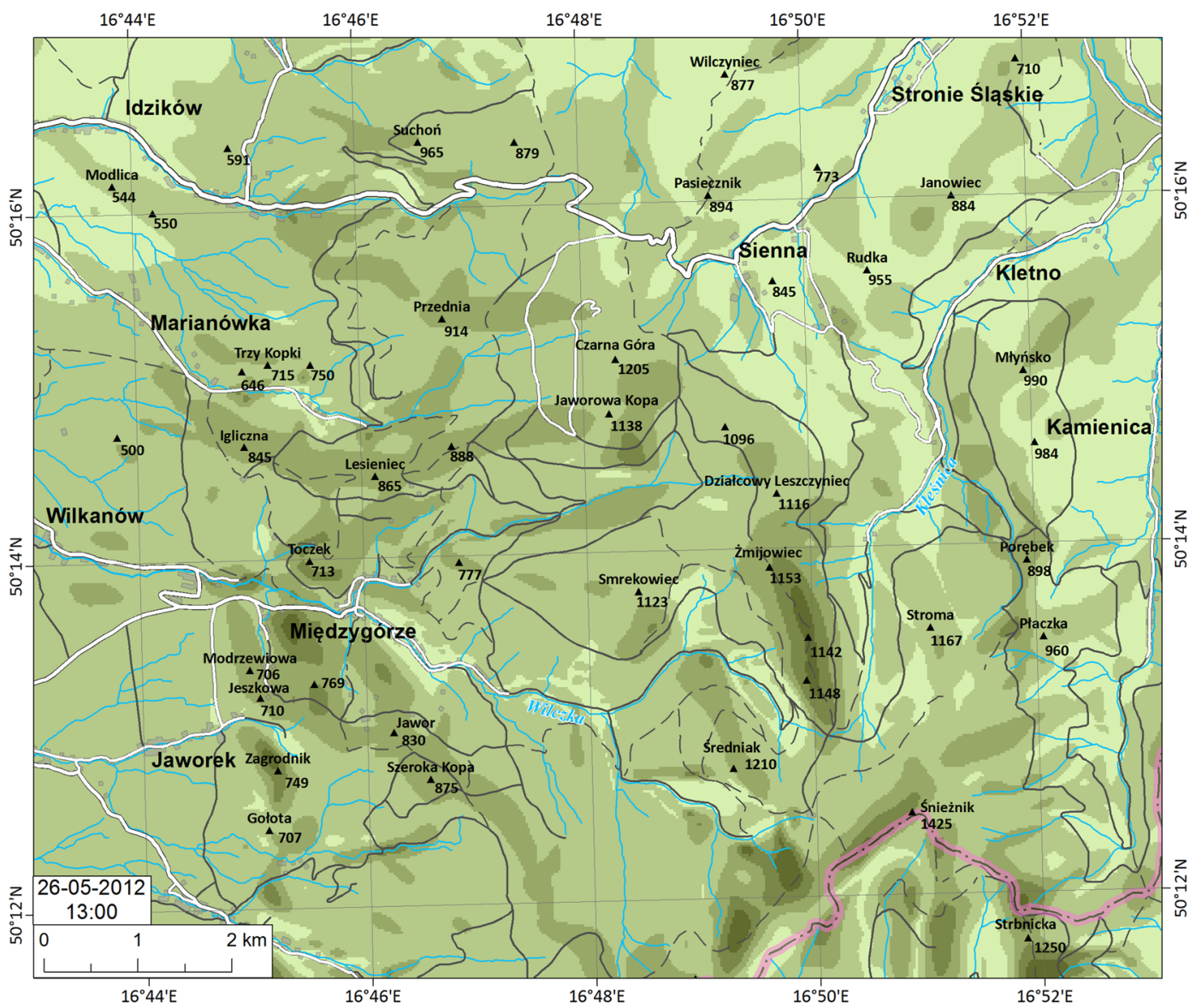

Range of modelled wind speed (height: $2 \mathrm{~m}$ ) [m/s]

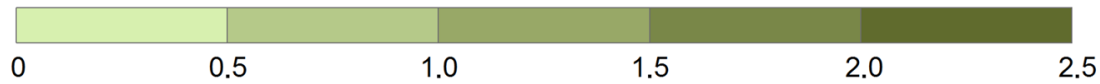

Figure 14

Spatial distribution of modelled wind velocity range (26 May 2012; 13:00). The values $\left(V_{\max }-V_{\min }\right)$ were calculated from results of 20 simulations based on various combinations of the input measurement points (containing at least two points). A constant roughness length $\left(z_{0}=0.05 \mathrm{~m}\right)$ was assumed

$100-\mathrm{m}$ and $250-\mathrm{m}$ resolution, show that including variable roughness length information improves the results of modelling in a resolution consistent with the land use data source. This is particularly noticeable in the case of points placed in forested areas (Czarna Góra, Mariańskie Skały, Żmijowa Polana, Średniak); a particular example is the Czarna Góra location, for which RMSE decreased from 3.9 to $0.4 \mathrm{~m} / \mathrm{s}$. The results of an additional experimental simulation, which included roughness information from the original CLC 2006 datasets, clearly show the influence of incorrect input data on the model's performance (Table 6). The difference between the calculated $\mathrm{RMSE}_{\mathrm{v}}$ is especially high in the case of Śnieżnik $2(3.2 \mathrm{~m} / \mathrm{s})$.

In some locations, relatively high error values tend to occur regardless of roughness length information (Śnieżnik 2, Jaworek, Idzików). This was probably the consequence of two tendencies of the model: the first to overestimate velocity in points placed at the highest altitudes (Śnieżnik 2) and the second to underestimate velocity in points placed at low altitudes or inside landforms with a spatial span exceeding the calculation domain range (Międzygórze 2, Jaworek, Idzików). In the second case a potential solution might be to expand the domain 


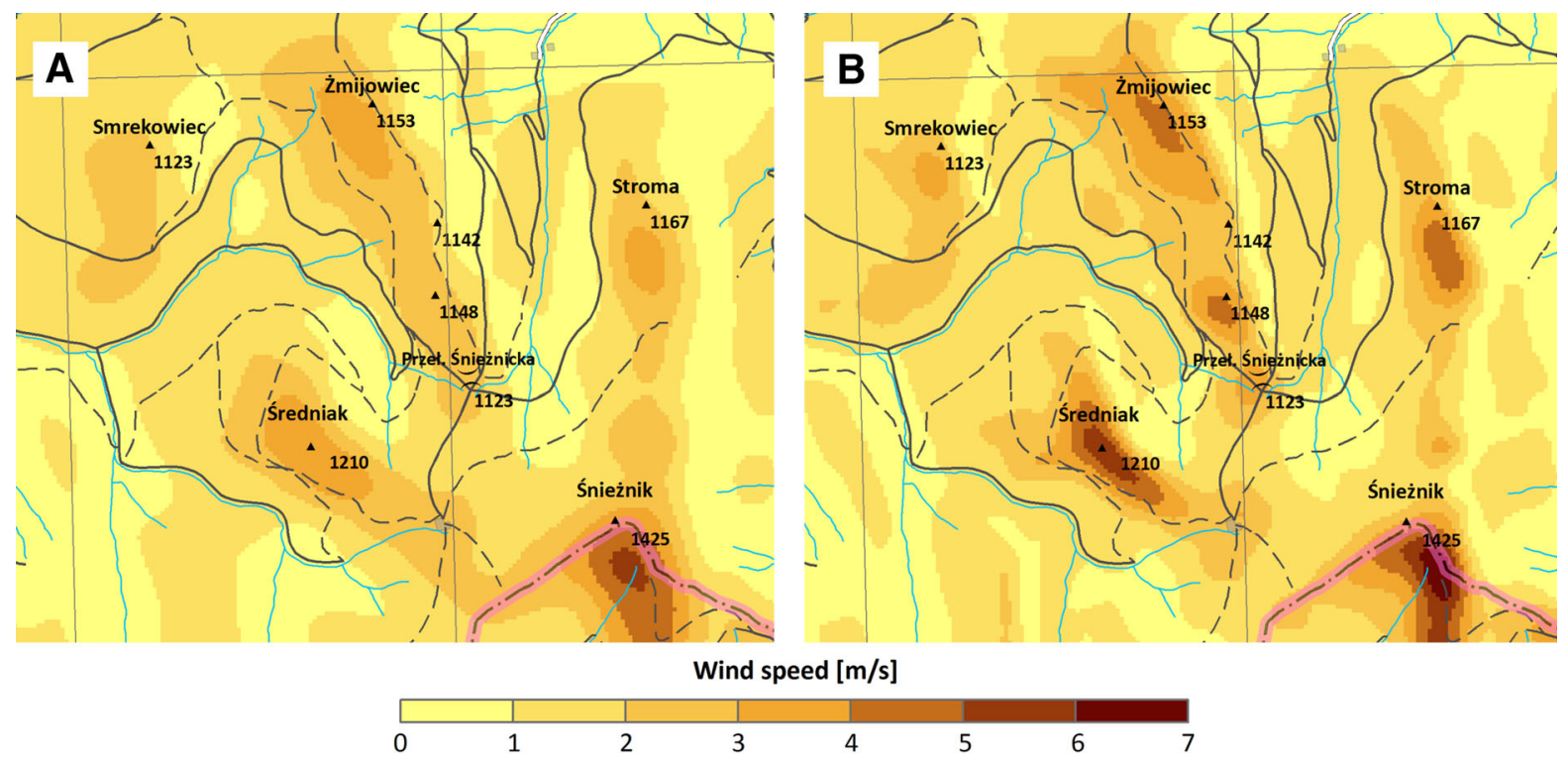

Figure 15

Example of wind velocity modelling results calculated within various spatial resolutions (a $250 \mathrm{~m}, \mathbf{b} 100 \mathrm{~m})$; the modelling was based on data from Śnieżnik 1 and Łąki Myśliwskie measurement points (26 November 2011; 13:00) with roughness length information derived from CLC 2006

area, however this shall be a subject of further experiments.

The results of Student's $t$ test indicate that changing the particular parameters of Canyon's setup may affect the results of the modelling with varied significance (Table 7). Within a $100 \mathrm{~m}$ resolution, the inclusion of the roughness information derived from CLC 2006 instead of a constant value of $0.05 \mathrm{~m}$ implied changes in the model's performance detected by 11 of 15 validation points. The same change, but within the coarser $(250 \mathrm{~m})$ resolution, affected 10 points and the overall impact was weaker. On the other hand, changes of the domain resolution caused significant changes in nine points (CLC 2006 roughness) and only in seven points if the constant roughness value was assumed. Finally, the exchange of DEMs (GLS DEM to DTED), caused the least noticeable changes in the modelled wind fields (only five points were affected).

The accuracy of the presented results may be considered as mediocre as compared with the results of other studies presented in the Introduction section. The achieved mean $\mathrm{RMSE}_{\mathrm{v}}$ values at best were no lower than $1.0 \mathrm{~m} / \mathrm{s}$. Nevertheless, some improvement was accomplished comparing the results of this study to the modelling conducted in test sites of Poiares and Trevim (Lopes 2003) (Table 8). However, it should be emphasized that the mentioned study was based on longer simulation periods, thus it presented rather an average model performance. Still, it is encouraging that in the mentioned studies input wind data were obtained from readings taken on masts higher than $5 \mathrm{~m}$. In this case it is justified to expect smaller sensitivity to the effects of roughness length spatial variability and, in consequence, higher values of performance indices. However, it should be noted that the $I_{\mathrm{v}}$ index is relative to the measured velocity; as such it should be used with caution as a basis for any comparisons.

\section{Conclusions}

The presented case study shows how remote sensing data may be used in the process of diagnostic modelling of a wind velocity field. Under the assumed methodical approach (limited number of observations taken by handheld anemometers), a very careful selection of modelled time-periods is crucial for obtaining feasible results of the modelling. It 


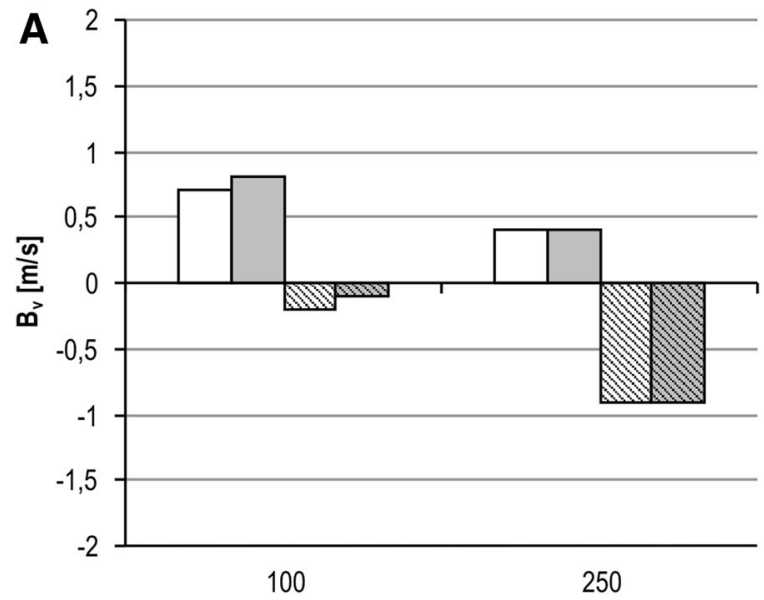

Domain's resolution [m]

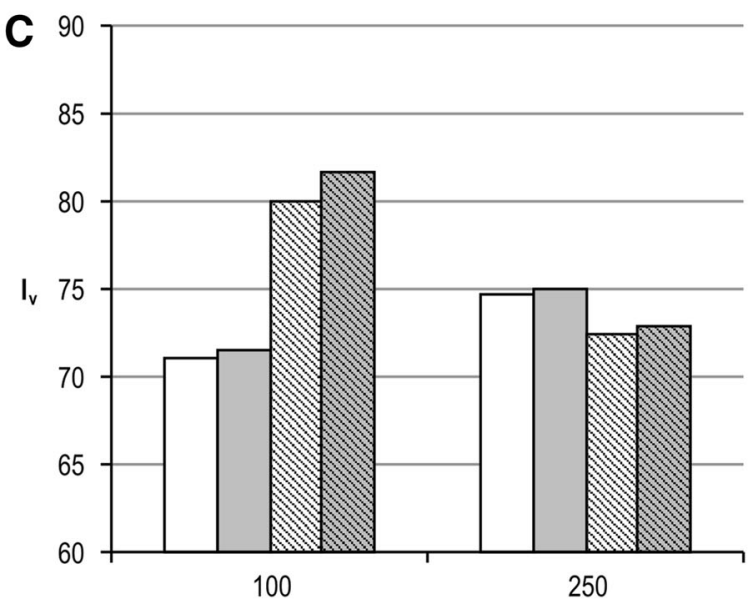

Domain's resolution $[\mathrm{m}]$
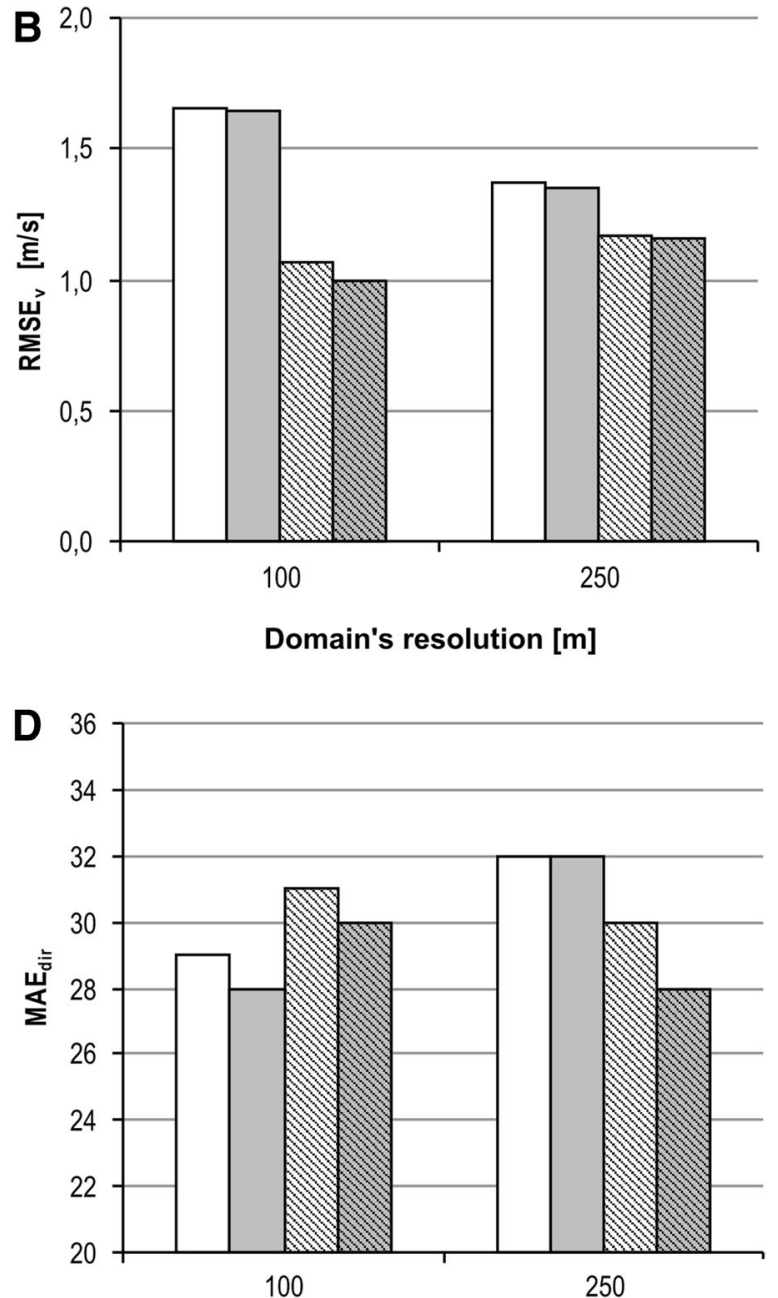

Domain's resolution $[\mathrm{m}]$

$\square$ GLSDEM $\square$ DTED 图GLSDEM+CLC2006 图DTED+CLC2006

Figure 16

Impact of domain's resolution on the overall values of wind field modelling performance indices: a mean $B_{\mathrm{v}}$, b mean RMSE $\mathrm{v}_{\mathrm{v}}$, c mean $I_{\mathrm{v}}$, d mean $\mathrm{MAE}_{\mathrm{dir}}$. Bar fill indicates various input elevation and roughness data configuration: white GLS DEM with uniform roughness, grey DTED with uniform roughness, patterned white GLS DEM with CLC 2006 roughness, patterned grey DTED with CLC 2006 roughness

should be emphasized that diagnostic models run well only during the occurrence of specific meteorological conditions (connected with strong and constant synoptic forcing of the air flow). Hence, all of further conclusions are limited to the aforementioned circumstances.

The results of the study clearly demonstrate the significance of roughness length information derived from remote sensing (in this case: CLC 2006) data in this type of modelling. The quality of the used data was high enough to achieve results comparable with other studies which present applications of diagnostic models. However, using raw CLC 2006 data is not recommended (in mountainous terrain), due to the aforementioned inaccuracies. Before generating roughness length information, where practicable, this 
Table 4

Mean error measures calculated for particular validation points within selected model's resolutions and with an assumption of constant roughness length (above-for DTED elevation model; below-for GLS DEM)

\begin{tabular}{|c|c|c|c|c|c|c|c|c|c|c|}
\hline \multirow[t]{2}{*}{ Station name } & \multicolumn{5}{|c|}{ Domain resolution $=100 \mathrm{~m}$} & \multicolumn{5}{|c|}{ Domain resolution $=250 \mathrm{~m}$} \\
\hline & $B_{\mathrm{v}}$ & $\mathrm{RMSE}_{\mathrm{v}}$ & $I_{\mathrm{v}}$ & $\mathrm{MAE}_{\mathrm{dir}}$ & $I_{\text {dir }}$ & $B_{\mathrm{v}}$ & $\mathrm{RMSE}_{\mathrm{v}}$ & $I_{\mathrm{v}}$ & $\mathrm{MAE}_{\text {dir }}$ & $I_{\mathrm{dir}}$ \\
\hline \multicolumn{11}{|l|}{ DTED } \\
\hline Czarna Góra & 3.9 & 3.9 & 35 & 26 & 95 & 2.9 & 2.9 & 46 & 28 & 94 \\
\hline Hala pod Śnieżnikiem & 1.7 & 1.9 & 73 & 25 & 93 & 1.5 & 1.7 & 75 & 29 & 92 \\
\hline Idzików & -2.2 & 2.2 & 46 & 26 & 94 & -2.2 & 2.2 & 46 & 28 & 93 \\
\hline Jaworek & -1.8 & 2.0 & 60 & 27 & 93 & -2.0 & 2.1 & 56 & 26 & 93 \\
\hline Jaworek Górny & 0.7 & 1.0 & 87 & 27 & 94 & 0.4 & 0.8 & 89 & 23 & 95 \\
\hline Kletno & -1.2 & 1.3 & 78 & 28 & 93 & -1.3 & 1.4 & 75 & 25 & 95 \\
\hline Łąki Myśliwskie & 0.5 & 0.8 & 75 & 8 & 99 & 0.2 & 0.9 & 74 & 8 & 99 \\
\hline Mariańskie Skały & 1.7 & 1.7 & 78 & 8 & 99 & 0.9 & 1.0 & 87 & 10 & 99 \\
\hline Międzygórze 1 & 0.2 & 1.0 & 74 & 41 & 87 & 0.0 & 0.8 & 79 & 39 & 87 \\
\hline Międzygórze 2 & -0.4 & 0.5 & 78 & 95 & 46 & -0.2 & 0.5 & 81 & 143 & 12 \\
\hline Puchaczówka & 0.1 & 0.8 & 84 & 47 & 83 & -0.2 & 0.7 & 88 & 42 & 87 \\
\hline Śnieżnik 1 & 3.5 & 1.5 & 73 & 16 & 97 & 3.2 & 1.6 & 81 & 18 & 96 \\
\hline Śnieżnik 2 & 1.6 & 2.0 & 88 & 19 & 96 & 0.8 & 1.2 & 92 & 19 & 96 \\
\hline Średniak & 2.0 & 2.2 & 76 & 23 & 95 & 0.4 & 1.0 & 88 & 25 & 94 \\
\hline Żmijowa Polana & 1.8 & 1.8 & 67 & 9 & 99 & 1.7 & 1.7 & 68 & 9 & 99 \\
\hline Mean value & 0.8 & 1.6 & 72 & 28 & 91 & 0.4 & 1.4 & 75 & 32 & 89 \\
\hline \multicolumn{11}{|l|}{ GLS DEM } \\
\hline Czarna Góra & 3.9 & 3.9 & 35 & 28 & 94 & 2.9 & 2.9 & 46 & 28 & 94 \\
\hline Hala pod Śnieżnikiem & 1.3 & 1.6 & 77 & 27 & 92 & 1.6 & 1.9 & 73 & 27 & 93 \\
\hline Idzików & -2.3 & 2.3 & 42 & 24 & 95 & -2.2 & 2.2 & 45 & 27 & 94 \\
\hline Jaworek & -1.8 & 2.0 & 60 & 26 & 93 & -2.0 & 2.1 & 56 & 27 & 93 \\
\hline Jaworek Górny & 0.5 & 0.8 & 89 & 26 & 94 & 0.2 & 0.7 & 89 & 21 & 96 \\
\hline Kletno & -1.2 & 1.3 & 78 & 28 & 93 & -1.4 & 1.4 & 75 & 25 & 94 \\
\hline Łąki Myśliwskie & 0.4 & 0.9 & 74 & 9 & 99 & 0.2 & 0.9 & 74 & 9 & 98 \\
\hline Mariańskie Skały & 1.8 & 1.8 & 76 & 9 & 99 & 0.9 & 1.0 & 87 & 10 & 99 \\
\hline Międzygórze 1 & 0.2 & 1.0 & 74 & 39 & 87 & 0.0 & 0.8 & 79 & 40 & 86 \\
\hline Międzygórze 2 & -0.4 & 0.6 & 74 & 102 & 40 & -0.1 & 0.4 & 87 & 149 & 9 \\
\hline Puchaczówka & -0.2 & 0.8 & 85 & 47 & 83 & -0.4 & 0.7 & 86 & 40 & 87 \\
\hline Śnieżnik 1 & 3.6 & 1.6 & 73 & 17 & 96 & 3.6 & 1.7 & 73 & 23 & 94 \\
\hline Śnieżnik 2 & 1.8 & 2.1 & 88 & 18 & 97 & 0.9 & 1.3 & 92 & 19 & 97 \\
\hline Średniak & 1.8 & 2.3 & 77 & 22 & 95 & 0.4 & 1.1 & 88 & 24 & 94 \\
\hline Żmijowa Polana & 1.8 & 1.8 & 67 & 9 & 99 & 1.5 & 1.5 & 71 & 9 & 99 \\
\hline Mean value & 0.7 & 1.7 & 71 & 29 & 90 & 0.4 & 1.4 & 75 & 32 & 88 \\
\hline
\end{tabular}

data should be compared to higher resolution aerial photos or orthophotomaps.

Surface roughness resolution has a marked impact on the modelled wind fields. In case of the resolution of the model this impact seems to be rather weaker. However, this issue cannot be definitely settled based on short-term, empirical results. It may be assumed that increasing the domain resolution further may improve the accuracy of the results, although this should be tested. Another way to improve the performance of the model would be probably the application of roughness data derived directly from orthophotomaps. This, in consequence, may necessitate the use of a different approach in roughness length class assignment. Moreover, an experiment involving the data from re-analysis driven dynamic models should also be conducted to further improve the initial wind fields.

The presented method of providing the input wind velocity and wind direction data proved to be 
Table 5

Mean error measures calculated for particular validation points within selected model's resolutions and with an assumption of roughness length derived from CLC 2006 dataset (above-for DTED elevation model; below-for GLS DEM)

\begin{tabular}{|c|c|c|c|c|c|c|c|c|c|c|}
\hline \multirow[t]{2}{*}{ Station name } & \multicolumn{5}{|c|}{ Domain resolution $=100 \mathrm{~m}$} & \multicolumn{5}{|c|}{ Domain resolution $=250 \mathrm{~m}$} \\
\hline & $B_{\mathrm{v}}$ & $\mathrm{RMSE}_{\mathrm{v}}$ & $I_{\mathrm{v}}$ & $\mathrm{MAE}_{\mathrm{dir}}$ & $I_{\text {dir }}$ & $B_{\mathrm{v}}$ & $\mathrm{RMSE}_{\mathrm{v}}$ & $I_{\mathrm{v}}$ & $\mathrm{MAE}_{\mathrm{dir}}$ & $I_{\mathrm{dir}}$ \\
\hline \multicolumn{11}{|l|}{ DTED + CLC 2006} \\
\hline Czarna Góra & -0.4 & 0.4 & 89 & 15 & 98 & -0.8 & 0.8 & 75 & 18 & 98 \\
\hline Hala pod Śnieżnikiem & -0.4 & 0.8 & 85 & 41 & 86 & -1.3 & 1.4 & 66 & 33 & 91 \\
\hline Idzików & -1.9 & 2.0 & 55 & 23 & 95 & -1.8 & 1.9 & 58 & 28 & 94 \\
\hline Jaworek & -1.2 & 1.4 & 76 & 26 & 93 & -1.6 & 1.7 & 66 & 25 & 94 \\
\hline Jaworek Górny & 1.0 & 1.3 & 83 & 32 & 91 & -0.3 & 0.7 & 86 & 31 & 92 \\
\hline Kletno & -0.4 & 0.7 & 91 & 30 & 93 & -0.4 & 0.7 & 91 & 32 & 92 \\
\hline Łąki Myśliwskie & 0.1 & 0.5 & 85 & 8 & 99 & -0.8 & 1.0 & 63 & 9 & 99 \\
\hline Mariańskie Skały & -0.3 & 0.5 & 93 & 6 & 100 & -1.5 & 1.5 & 71 & 7 & 100 \\
\hline Międzygórze 1 & 0.1 & 0.8 & 78 & 40 & 87 & -0.3 & 0.5 & 86 & 40 & 87 \\
\hline Międzygórze 2 & -0.4 & 0.5 & 77 & 54 & 79 & -1.1 & 1.1 & 29 & 67 & 67 \\
\hline Puchaczówka & -0.1 & 1.5 & 65 & 55 & 78 & -0.9 & 1.1 & 75 & 50 & 81 \\
\hline Śnieżnik 1 & 0.8 & 0.8 & 85 & 11 & 99 & 0.3 & 0.6 & 91 & 24 & 94 \\
\hline Śnieżnik 2 & 1.8 & 2.2 & 87 & 24 & 94 & -1.0 & 1.4 & 91 & 28 & 92 \\
\hline Średniak & -0.5 & 1.1 & 87 & 79 & 58 & -2.0 & 2.2 & 64 & 23 & 95 \\
\hline Żmijowa Polana & -0.4 & 0.5 & 87 & 13 & 98 & -0.7 & 0.7 & 80 & 14 & 98 \\
\hline Mean value & -0.1 & 1.0 & 82 & 30 & 90 & -0.9 & 1.2 & 73 & 28 & 92 \\
\hline \multicolumn{11}{|l|}{ GLS DEM + CLC 2006} \\
\hline Czarna Góra & -0.4 & 0.4 & 89 & 16 & 98 & -0.8 & 0.8 & 74 & 17 & 98 \\
\hline Hala pod Śnieżnikiem & -0.8 & 1.1 & 77 & 42 & 84 & -1.3 & 1.4 & 65 & 34 & 90 \\
\hline Idzików & -2.1 & 2.2 & 47 & 23 & 96 & -1.8 & 1.9 & 57 & 27 & 94 \\
\hline Jaworek & -1.3 & 1.5 & 75 & 27 & 93 & -1.5 & 1.7 & 69 & 27 & 93 \\
\hline Jaworek Górny & 0.8 & 1.1 & 86 & 31 & 92 & -0.3 & 0.7 & 87 & 30 & 92 \\
\hline Kletno & -0.3 & 0.7 & 92 & 28 & 93 & -0.4 & 0.7 & 91 & 25 & 95 \\
\hline Łąki Myśliwskie & -0.1 & 0.5 & 83 & 9 & 99 & -0.8 & 1.1 & 62 & 12 & 99 \\
\hline Mariańskie Skały & -0.4 & 0.5 & 92 & 6 & 100 & -1.5 & 1.5 & 71 & 8 & 99 \\
\hline Międzygórze 1 & 0.0 & 0.8 & 79 & 41 & 86 & -0.3 & 0.5 & 85 & 40 & 86 \\
\hline Międzygórze 2 & -0.6 & 0.7 & 68 & 53 & 79 & -1.1 & 1.1 & 31 & 104 & 38 \\
\hline Puchaczówka & -0.2 & 1.3 & 73 & 57 & 77 & -1.0 & 1.2 & 72 & 47 & 82 \\
\hline Śnieżnik 1 & 0.9 & 0.9 & 84 & 16 & 97 & 0.4 & 0.8 & 89 & 25 & 94 \\
\hline Śnieżnik 2 & 2.3 & 2.6 & 87 & 24 & 94 & -0.8 & 1.2 & 93 & 24 & 94 \\
\hline Średniak & -0.6 & 1.1 & 87 & 76 & 59 & -2.0 & 2.1 & 66 & 21 & 95 \\
\hline Żmijowa Polana & -0.7 & 0.7 & 79 & 13 & 98 & -0.8 & 0.8 & 76 & 14 & 98 \\
\hline Mean value & -0.2 & 1.1 & 80 & 31 & 90 & -0.9 & 1.2 & 72 & 30 & 90 \\
\hline
\end{tabular}

Table 6

Comparison of RMSE $E_{v}$ errors calculated for selected validation points with an assumption of roughness length derived from the original CLC 2006 dataset and the corrected one (simulation used GLS DEM and was performed within 100 grid space)

\begin{tabular}{lll}
\hline Station name & RMSE $_{\mathrm{v}}$ & \\
\cline { 2 - 3 } & Raw CLC 2006 roughness data & Corrected CLC 2006 roughness data \\
\hline Łąki Myśliwskie & 1.3 & 0.5 \\
Mariańskie Skały & 1.1 & 0.5 \\
Śnieżnik 2 & 5.8 & 2.6 \\
\hline
\end{tabular}

Table includes only points where difference of $\mathrm{RMSE}_{\mathrm{v}}$ exceeded $0.1 \mathrm{~m} / \mathrm{s}$ 
Table 7

Results (probability values) of the Student's t test for paired samples

\begin{tabular}{|c|c|c|c|c|c|}
\hline \multirow[t]{4}{*}{ Measurement point } & \multicolumn{5}{|c|}{ Probability values derived from the Student's $t$ test } \\
\hline & \multicolumn{5}{|l|}{$\mathrm{H}_{0}$ hypothesis } \\
\hline & \multicolumn{5}{|c|}{ The sample of absolute bias error of wind speed do not change in case of } \\
\hline & $\begin{array}{l}\text { Inclusion of variable } \\
\text { roughness length } \\
\text { information derived from } \\
\text { CLC } 2006 \text { instead of the } \\
\text { constant value }(0.05 \mathrm{~m}) \\
\text { within domain resolution } \\
\text { of } 100 \mathrm{~m}\end{array}$ & $\begin{array}{l}\text { Inclusion of variable } \\
\text { roughness length } \\
\text { information derived from } \\
\text { CLC } 2006 \text { instead of the } \\
\text { constant value }(0.05 \mathrm{~m}) \\
\text { within domain resolution } \\
\text { of } 250 \mathrm{~m}\end{array}$ & $\begin{array}{l}\text { Increment of } \\
\text { domain resolution } \\
\text { from } 250 \text { to } 100 \mathrm{~m} \\
\text { (roughness length } \\
\text { information derived } \\
\text { from CLC 2006) }\end{array}$ & $\begin{array}{l}\text { Increment of } \\
\text { domain } \\
\text { resolution from } \\
250 \text { to } 100 \mathrm{~m} \\
\text { (constant } \\
\text { roughness } \\
\text { length- } \\
0.05 \mathrm{~m} \text { ) }\end{array}$ & $\begin{array}{l}\text { Use of different DEMs: } \\
\text { DTED and GLS DEM } \\
\text { (domain's resolution- } \\
100 \mathrm{~m} \text {; roughness } \\
\text { length information } \\
\text { derived from CLC } 2006\end{array}$ \\
\hline Czarna Góra & 0.000 & 0.001 & 0.000 & 0.000 & 0.789 \\
\hline Hala p. Śnieżnikiem & 0.000 & 0.489 & 0.001 & 0.049 & 0.145 \\
\hline Idzików & 0.002 & 0.000 & 0.000 & 0.055 & 0.000 \\
\hline Jaworek & 0.000 & 0.000 & 0.000 & 0.014 & 0.745 \\
\hline Jaworek Górny & 0.012 & 0.689 & 0.483 & 0.614 & 0.001 \\
\hline Kletno & 0.001 & 0.000 & 0.724 & 0.000 & 0.682 \\
\hline Łąki Myśliwskie & 0.135 & 0.491 & 0.013 & 0.418 & 0.643 \\
\hline Mariańskie Skały & 0.001 & 0.044 & 0.000 & 0.000 & 0.820 \\
\hline Międzygórze 1 & 0.059 & 0.177 & 0.196 & 0.082 & 0.363 \\
\hline Międzygórze 2 & 0.215 & 0.000 & 0.000 & 0.061 & 0.008 \\
\hline Puchaczówka & 0.008 & 0.038 & 0.869 & 0.541 & 0.271 \\
\hline Śnieżnik 1 & 0.000 & 0.000 & 0.128 & 0.884 & 0.041 \\
\hline Śnieżnik 2 & 0.013 & 0.736 & 0.171 & 0.069 & 0.058 \\
\hline Średniak & 0.060 & 0.005 & 0.000 & 0.004 & 0.908 \\
\hline Żmijowa Polana & 0.006 & 0.009 & 0.036 & 0.004 & 0.019 \\
\hline Mean value & 0.034 & 0.179 & 0.175 & 0.186 & 0.366 \\
\hline Standard deviation & 0.062 & 0.274 & 0.285 & 0.284 & 0.356 \\
\hline
\end{tabular}

The test was performed on the absolute values of wind velocity bias in order to determinate the significance of particular changes of the model's parameters in context of the model's performance

Bold numbers indicate probability values lower than 0.05

Table 8

Comparison of Canyon CFD solver performance indices calculated for various test sites

\begin{tabular}{lllll}
\hline Test site & $\begin{array}{l}\text { Poiares region } \\
\text { (Lopes 2003) }\end{array}$ & $\begin{array}{l}\text { Trevim region } \\
\text { (LoPEs 2003) }\end{array}$ & $\begin{array}{l}\text { Śnieżnik Massif } \\
\text { (constant roughness) }\end{array}$ & $\begin{array}{l}\text { Śnieżnik Massif } \\
\text { (CLC 2006 roughness) }\end{array}$ \\
\hline Mean $I_{\mathrm{v}}$ & 56 & 41 & 71 & 80 \\
Mean $I_{\text {dir }}$ & 90 & 63 & 90 & 90 \\
\hline
\end{tabular}

relatively useful, especially given the lack of data from other sources. In this case, the issue of defining measurement locations (the most representative in the considered model and roughness data resolution) seems to be still open and ready for further studies and discussion. 


\section{Acknowledgments}

The author is very grateful to: Romuald Jancewicz, Marzena Józefczyk, Aleksandra Karbowniczak, Dariusz Miazgowicz, Maurycy Urbanowicz and Remigiusz Żukowski for their support during field measurements of wind velocity, Tymoteusz Sawiński for technical support, Michał Godek, Tomasz Niedzielski, Mariusz Szymanowski and Małgorzata Wieczorek for discussion on problematic issues which occurred during the work on this article. Kaindl Windmaster 2 anemometers were used by kind permission of Department of Climatology and Atmosphere Protection, University of Wrocław. WindStation 2.0.10 software was developed and provided by António Manuel Gameiro Lopes (Department of Mechanical Engineering, University of Coimbra). ArcInfo 9.3.1 software was developed by ESRI and provided by Laboratory of Geographic Information Systems and Computer Cartography in Department of Cartography, University of Wrocław. Meteorological data used in presented study were provided by Department of Atmospheric Science at the University of Wyoming, National Oceanic and Atmospheric Administration, The Austrian Central Institute for Meteorology and Geodynamics (ZAMG), German Weather Service and The Institute for Meteorology at the Free University of Berlin. DTED elevation model was provided by Department of Cartography, University of Wrocław. GLS DEM elevation model was provided by Global Land Cover Facility, University of Maryland. Corine Land Cover 2006 datasets were provided by European Environmental Agency. Orthophotomaps used in this study were provided GEODIS BRNO, spol. s.r.o. and by Geodesic and Cartographic Documentation Center (CODGiK). Finally, the author greatly appreciate two anonymous reviewers for their valuable comments and constructive suggestions to improve the manuscript.

Open Access This article is distributed under the terms of the Creative Commons Attribution License which permits any use, distribution, and reproduction in any medium, provided the original author(s) and the source are credited.
AbBes, M., Belhadj, J. (2012), Wind resource estimation and wind park design in El-Kef region, Tunisia, Energy 40, 348-357.

BARRY, R.G., Mountain weather and climate (University Press, Cambridge 2008).

BARNA, M., LAMB, B. (2000), Improving ozone modeling in regions of complex terrain using observational nudging in a prognostic meteorological model, Atmospheric Environment 34, 48894906.

Beaucage, P., Brower, M.C. (2012), Wind flow model performance. Do more sophisticated models produce more accurate wind resource estimates? AWS Truepower LLC Report, http:// www.awstruepower.com/wp-content/uploads/2012/02/WindFlow-Model-Performance.pdf.

BöHNER, J., ANTONIć, O., Land-surface parameters specific to topoclimatology. In Geomorphometry: concepts, software, applications. (eds. Hengl T., Reuter H. I.) (Elsevier 2007) pp. 195-225.

Chandrasekar, A., Philbrick C.R., Clark, R., Doddridge, B., Georgopoulos, P. (2003), Evaluating the performance of a computationally efficient MM5/CALMET system for developing wind field inputs to air quality models, Atmospheric Environment 37, 3267-3276.

Cox, R.M., Sontowski, J., Dougherty, C.M. (2005), An evaluation of three diagnostic wind models (CALMET, MSCIPUF, and SWIFT) with wind data from the Dipole Pride 26 field experiments, Meteorological Applications 12, 329-341.

Desiato, S., Finardi, G., Brusasca, G., Morselli, M.G. (1998), TRANSALP 1989 experimental campaign - I. Simulation of 3D flow with diagnostic wind field models, Atmospheric Environment 32, 1141-1156.

EmeIs, S., Knoche, H.R., Applications in meteorology. In Geomorphometry: concepts, software, applications. (eds. Hengl T., Reuter H. I.) (Elsevier 2007) pp. 603-623.

Emery, C., TAI, E., YARwood, G., Enhanced meteorological modeling and performance evaluation for two Texas ozone episodes. (ENVIRON International Corporation, 2001).

JACKSON, P.S., HUNT, J.C.R. (1975), Turbulent wind flow over a low hill, Quarterly Journal of the Royal Meteorological Society 101, 929-955.

JENIK, J., Alpinská vegetace Krkonoš, Králického Sněžniku a Hrubého Jeseniku. Teorie anemo-orografických systémů. (Nakl. CAV, Praha 1961).

LOPES, A.M.G. (2003), WindStation - a software for the simulation of atmospheric flows over complex topography, Environmental Modelling \& Software 18, 81-96.

LoPES, A.M.G. (2011), WindStation 2.0.7: Users Manual.

Morales, L., Lang, F., Mattar, C. (2012), Mesoscale wind speed simulation using CALMET model and reanalysis information: An application to wind potential, Renewable Energy 48, 57-71.

Nelson, A., Reuter, H., Gessler, P., DEM production methods and sources. In Geomorphometry: concepts, software, applications. (eds. Hengl T., Reuter H. I.) (Elsevier 2007) pp. 65-85.

PIASECKI, J., Wybrane cechy klimatu Masywu Śnieżnika, In Masyw Śnieżnika. Zmiany w środowisku przyrodniczym (eds. Jahn A., Kozłowski S., Pulina M.) (PAE, Warszawa 1996) pp. 189-206. 
Piasecki, J., Sawiński, T., The Niedźwiedzia Cave in the climatic environment of the Kleśnica Valley (Śnieżnik Massif), In Karst of the Częstochowa Upland and of the Eastern Sudetes: palaeoenviroments and protection (eds. Stefaniak K., Tyc A., Socha P.) (University of Silesia, Sosnowiec-Wrocław 2009) pp. 423-454.

Ratto, C. F., Festa, R., Romeo, C. (1994), Mass-consistent models for wind fields over complex terrain: The state of art, Environmental Software 9, 247-268.

Silva, J., Ribeiro, C., Guedes, C. (2007), Roughness length classification of Corine Land Cover Classes, Conference Proceedings European Wind Energy Conference 2007.

Skamarock, W.C, Klemp, J.B., Dudhia, J., Gill, D.O., Barker, D.M., WANG, W., Powers, J.G., A description of the advanced research WRF Version 2. NCAR Technical Note No. 458, (National Center for Atmospheric Research, Boulder 2005), http://www.mmm.ucar.edu/wrf/users/docs/arw_v2.pdf.

SoвıK, M., Błaś, M., Wyjątkowe zdarzenia meteorologiczne, In Wyjątkowe zdarzenia przyrodnicze na Dolnym Śląsku i ich skutki. Rozprawy Naukowe Instytutu Geografii i Rozwoju Regionalnego Vol. 14 (ed. Migoń P.) (Uniwersytet Wrocławski, Wrocław 2010) pp. 35-80.

TRuHETZ, H., High resolution wind field modelling over complex topography: analysis and future scenarios. (Wegener Center for
Climate and Global Change, Scientific Report No. 32-2010, Graz 2010).

UCHIDA, T., Онуа, Y. (2003), Large-eddy simulation of turbulent airflow over complex terrain. Journal of Wind Engineering and Industrial Aerodynamics 91, 219-229.

Undén, P., Rontu, L., JÄrvinen, H., Lynch, P., Calvo, J., Cats, G., Cuxart, J., Eerola, K., Fortelius, C., Garcia-Moya, J.A., Jones, C., Lenderlink, G., McDonald, A., McGrath, R., Navascués, B., Woetman, N., Ødegaard, V., Rodriguez, E., Rummukainen, M., Rõõm, R., Sattler, K., Hansen Sass, B., SAvijärvi, H., WIChers Schreur, B., Sigg, R., The, H., Tijm, A., HIRlAM-5 Scientific Documentation, Tech. Rep. (Swedish Meteorological and Hydrological Institute, Norrköping 2002).

UnDHEIM, O., The non-linear microscale flow solver 3DWinddevelopments and validation. (Doctoral Theses at NTNU, Trondheim 2005).

Wakes, S.J., Maegli, T., Dickinson, K.J., Hilton, M.J. (2010), Numerical modelling of wind flow over a complex topography, Environmental Modelling \& Software 25, 237-247.

World Meteorological Organization, Guide to Meteorological Instruments and Methods of Observation, Tech. Rep. 8 (Seventh Edition). (Secretariat of World Meteorological Organization, Geneva 2008). 